\title{
Biomineralization of U(VI) Phosphate Promoted by Microbially-Mediated Phytate Hydrolysis in Contaminated Soils
}

\author{
Kathleen R. Salome ${ }^{1}$, Melanie J. Beazley ${ }^{2,4}$, \\ Samuel M. Webb ${ }^{3}$, Patricia A. Sobecky², Martial Taillefert ${ }^{*}$
}

${ }^{1}$ School of Earth \& Atmospheric Sciences, Georgia Institute of Technology, Atlanta, GA 30332

${ }^{2}$ Department of Biological Sciences, University of Alabama, Tuscaloosa, AL 35487

${ }^{3}$ Stanford Synchrotron Radiation Lightsource, Menlo Park, CA 94025

${ }^{4}$ Department of Chemistry, University of Central Florida, Orlando, FL 32816

*Corresponding author phone: (404)-894-6043; e-mail: mtaillef@eas.gatech.edu

Submitted to Geochimica et Cosmochimica Acta

$8 / 3 / 16$ 


\section{ABSTRACT}

The bioreduction of uranium may immobilize a significant fraction of this toxic contaminant in reduced environments at circumneutral $\mathrm{pH}$. In oxic and low $\mathrm{pH}$ environments,

4 however, the low solubility of U(VI)-phosphate minerals also makes them good candidates for

5 the immobilization of U(VI) in the solid phase. As inorganic phosphate is generally scarce in

6 soils, the biomineralization of U(VI)-phosphate minerals via microbially-mediated

7 organophosphate hydrolysis may represent the main immobilization process of uranium in these

8 environments. In this study, contaminated sediments were incubated aerobically in two $\mathrm{pH}$

9 conditions to examine whether phytate, a naturally-occurring and abundant organophosphate in 10 soils, could represent a potential phosphorous source to promote U(VI)-phosphate

11 biomineralization by natural microbial communities. While phytate hydrolysis was not evident 12 at $\mathrm{pH}$ 7.0, nearly complete hydrolysis was observed both with and without electron donor at $\mathrm{pH}$ 13 5.5, suggesting indigenous microorganisms express acidic phytases in these sediments. While 14 the rate of hydrolysis of phytate generally increased in the presence of uranium, the net rate of 15 inorganic phosphate production in solution was decreased and inositol phosphate intermediates 16 were generated in contrast to similar incubations conducted without uranium. These findings 17 suggest uranium stress enhanced the phytate-metabolism of the microbial community, while 18 simultaneously inhibiting phosphatase production and/or activity by the indigenous population. 19 Finally, phytate hydrolysis drastically decreased uranium solubility, likely due to formation of 20 ternary sorption complexes, U(VI)-phytate precipitates, and U(VI)-phosphate minerals. Overall, 21 the results of this study provide evidence for the ability of natural microbial communities to 22 liberate phosphate from phytate in acidic sediments, possibly as a detoxification mechanism, and 23 demonstrate the potential utility of phytate-promoted uranium immobilization in subsurface 
1 environments. These processes should be investigated in more detail with pure cultures isolated 
Since the end of the Cold War Era, the United States Department of Energy (DOE) has

shifted its focus from nuclear weapons proliferation to remediation of radionuclide and heavy metal contamination at former weapons development sites (DOE, 1997). The large number of DOE-managed facilities with a wide range of subsurface geochemical conditions, ranging from highly acidic (Oak Ridge, TN) to alkaline pH (Hanford, WA), makes developing a prescriptive bioremediation strategy appropriate for all subsurface conditions complicated (DOE, 1997). In particular, the presence of acidic environments, where metal reduction is unfavorable, commands the development of creative in situ remediation solutions for environmental uranium contamination (Istok et al., 2004; Kelly et al., 2008; North et al., 2004; Sitte et al., 2010; Van Nostrand et al., 2011; Wu et al., 2006a; Wu et al., 2006b).

The mobility of uranium in the subsurface is controlled by a combination of surface complexation reactions, precipitation reactions, and redox processes (Finch and Murakami, 1999; Hsi and Langmuir, 1985; Langmuir, 1997). Uranium exists primarily as U(IV) or U(VI) depending on the prevailing environmental redox conditions. In oxidizing conditions, U(VI) exists as the aqueous uranyl ion $\mathrm{UO}_{2}{ }^{2+}$ and its hydroxyl complexes. Above $\mathrm{pH}$ 7.0, carbonates may enhance uranyl mobility by forming soluble uranyl-carbonate complexes and promoting the dissolution of U(IV) and U(VI) minerals (Langmuir, 1978, 1997). In addition, the presence of calcium at this $\mathrm{pH}$ may inhibit uranyl reduction or $\mathrm{U}(\mathrm{VI})$-phosphate precipitation through formation of ternary calcium-uranyl-carbonate complexes (Brooks et al., 2003; Luo et al., 2007), though uranyl phosphate precipitation may prevail when phosphate concentrations are elevated (Salome et al., 2013). In contrast, below circumneutral pH, strong sorption to metal oxides (Han et al., 2007; Hsi and Langmuir, 1985; Plathe et al., 2013; Waite et al., 1994), clays (Bai et al., 
2009; Grabias et al., 2014; Meleshyn et al., 2009), and natural organic matter (NOM) (Li et al.,

27 2014) and the formation of highly stable and sparingly soluble precipitates with phosphate may

28 limit uranyl mobility in the environment (Finch and Murakami, 1999; Langmuir, 1997). In

29 reducing conditions, U(VI) may either be chemically (Hua and Deng, 2008; Liger et al., 1999;

Missana et al., 2003; O'Loughlin et al., 2003; Wersin et al., 1994) or microbially (Lovley et al.,

1991; Sanford et al., 2007; Tebo and Obraztsova, 1998; Wade and DiChristina, 2000) reduced to

$\mathrm{U}(\mathrm{IV})$ and precipitate as uraninite $\left(\mathrm{UO}_{2(\mathrm{~s})}\right)$ (Finch and Murakami, 1999; Langmuir, 1997) or

other non-uraninite U(IV) mineral phases (Alessi et al., 2014; Boyanov et al., 2011; Fletcher et

al., 2010). However, the reintroduction of oxygen (Langmuir, 1997; Murphy and Shock, 1999;

Wu et al., 2007) or the presence of $\mathrm{NO}_{2}{ }^{-}$(Senko et al., 2002; Senko et al., 2005a), Fe(III) (Senko

et al., 2002; Senko et al., 2005b; Wan et al., 2005), or $\mathrm{MnO}_{2}$ (Fredrickson et al., 2002) in reducing conditions may remobilize U(IV)-precipitates to soluble U(VI) species.

Thus far, in situ bioremediation of uranium contaminations has primarily focused on the formation of various reduced uranium mineral products via microbially-catalyzed reduction of U(VI), known as bioreduction (Bernier-Latmani et al., 2010; Istok et al., 2004; Kelly et al., 2008;

41 Lovley et al., 1991; North et al., 2004; Sharp et al., 2011; Wade and DiChristina, 2000; Wu et

42 al., 2006b). Unfortunately, the low pH, elevated nitrate, and oxidizing conditions present in 43 some contaminated areas inhibit this process (Finneran et al., 2002; Wu et al., 2006a; Wu et al., 44 2006b), making the precipitation of U(VI)-phosphate minerals a potentially appealing alternative 45 to bioreduction. As orthophosphate directly amended to the subsurface is rapidly immobilized 46 thus limiting its transport (Wellman et al., 2006), research has focused on the addition of 47 organophosphates to subsurface sediments to promote microbially-mediated organophosphate 48 hydrolysis coupled to the chemical precipitation of sparingly soluble U(VI)-phosphate minerals 
49 in a process termed biomineralization (Beazley et al., 2007, 2009; Beazley et al., 2011; Macaskie

50 et al., 1994; Shelobolina et al., 2009). To fulfill their phosphorus requirement when faced with

51 nutrient limitations, microorganisms encode genes for various phosphohydrolase (phosphatase)

52 enzymes that catalyze the hydrolysis of organophosphates and release orthophosphate (Macaskie

53 et al., 1994). In addition, uranium stress may induce microbial phosphatase expression as a

54 metal detoxification mechanism (Barnett et al., 2002; Knox et al., 2008; Macaskie et al., 1994).

55 Although previous research has demonstrated that microbial hydrolysis of synthetic

56 organophosphates immobilizes more than $98 \%$ of $\mathrm{U}(\mathrm{VI})$ as $\mathrm{U}(\mathrm{VI})$-phosphate minerals in both

57 oxic (Beazley et al., 2007, 2009; Beazley et al., 2011; Martinez et al., 2007; Shelobolina et al.,

58 2009) and suboxic (Beazley et al., 2009; Salome et al., 2013; Shelobolina et al., 2009)

59 conditions, the potential of naturally-occurring organophosphates as a source of inorganic

60 phosphorus to promote U(VI)-phosphate biomineralization has not been examined.

Inositol hexaphosphate $\left(\mathrm{IP}_{6}\right)$, also known as phytate, is a phosphorylated inositol with six

62 attached phosphate groups (Figure S1) that is widely synthesized by plants for phosphorus

63 storage and may represent the dominant organophosphate compound in terrestrial environments

64 (Turner et al., 2002), with concentrations as high as $1 \mathrm{~g} \mathrm{P} / \mathrm{kg}$ soil (Turner, 2007). The

65 accumulation of $\mathrm{IP}_{6}$ in soils suggests that it is relatively unavailable for biological uptake or that

66 its bioavailability depends on the presence of specific enzymes (Turner et al., 2002). Although

$67 \mathrm{IP}_{6}$ is chemically stable above $\mathrm{pH} 1$ and is not hydrolyzed by conventional phosphohydrolases

68 (Turner et al., 2002), phytase enzymes may catalyze its hydrolysis to lower inositol derivatives

$69\left(\mathrm{IP}_{\mathrm{X}}, \mathrm{x}=1-5\right)$ and inorganic phosphate (Irving and Cosgrove, 1974). Phytase enzymes are

70 substrate-specific phosphatases (Oh et al., 2004) that include both bacterial histidine acid

71 phosphatases (HAP) (activated between $\mathrm{pH} 2$ and 6) and bacterial $\beta$-propeller phytases (activated 
72 at or above $\mathrm{pH}$ 7.0) (Oh et al., 2004). Acidic phytase enzymes are inhibited by divalent cat/ions

73 (especially $\left.\mathrm{Ca}^{2+}\right)\left(\mathrm{Oh}\right.$ et al., 2004), whereas alkaline phytase require $\mathrm{Ca}^{2+}$ for enzymatic function

74 (Ha et al., 2000). Because of its highly negative charge above pH 2 (Figure 1A), phytate

75 interacts strongly with soils (Degroot and Golterman, 1993; Johnson et al., 2012) and efficiently

76 chelates metals to form sparingly soluble complexes (Martin and Evans, 1987; Turner et al.,

77 2002). Although calcium phytate was demonstrated to chemically precipitate $\mathrm{U}(\mathrm{VI})$ by ion

78 exchange (Knox et al., 2008; Nash et al., 1998; Seaman et al., 2003), the microbially-facilitated

79 precipitation of $\mathrm{U}(\mathrm{VI})$-phosphate minerals by phytate-mineralizing bacteria has yet to be

80 examined. The objectives of this study were to investigate the ability of the natural microbial

81 community in uranium-contaminated sediments of the ORFRC to metabolize phytate, examine

82 the dependence of this metabolism on $\mathrm{pH}$ and the addition of an electron donor, and determine

83 the geochemical conditions required to induce U(VI)-phosphate biomineralization coupled to 84 microbial phytate degradation.

\section{EXPERIMENTAL}

86 All experiments were conducted in artificial groundwater, consisting of $15.4 \mathrm{mM} \mathrm{NO}_{3}^{-}$, $870.81 \mathrm{mM} \mathrm{SO}_{4}^{2-}, 0.41 \mathrm{mM} \mathrm{Cl}^{-}, 7.5 \mathrm{mM} \mathrm{Na}^{+}, 7.9 \mathrm{mM} \mathrm{K}^{+}, \mathrm{Mg}^{2+} 0.81 \mathrm{mM}, \mathrm{Ca}^{2+} 0.2 \mathrm{mM}, \mathrm{Mn}^{2+} 5.1$ $88 \mu \mathrm{M}$, and $\mathrm{Fe}^{2+} 2 \mu \mathrm{M}$ buffered at either $\mathrm{pH} 5.5$ or $\mathrm{pH} 7.0$ with $50 \mathrm{mM}$ 2-(N89 Morpholino)ethanesulfonic acid (pH 5.5) or 4-(2-hydroxyethyl)-1-piperazineethanesulfonic acid $90 \quad(\mathrm{pH} 7.0)$.

\section{$91 \quad 2.1$ Abiotic Precipitation of U(VI)-Phytate}

To ensure phytate does not abiotically precipitate with uranium in the conditions of the

93 incubations, triplicate solutions of $200 \mu \mathrm{M}$ uranyl acetate (Spectrum) were equilibrated for 48

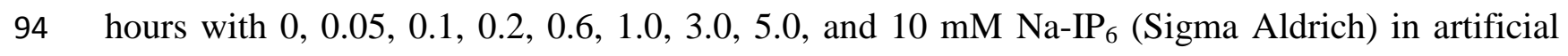


groundwater buffered at either $\mathrm{pH} 5.5$ or 7.0. After equilibration, a small aliquot was filtered through a $0.2 \mu \mathrm{m}$ pore size polyethersulfone (PES) membrane filter (Puradisc, Whatman) and preserved in $2 \%$ trace metal grade nitric acid for uranium analysis.

\subsection{Sediment Slurry Incubations}

To examine the phytate metabolism of the natural microbial community, ORFRC Area 3 sediments (well number: FWB134-08-03, core depth: 6.5-7.5 m) were incubated in triplicate with artificial groundwater for 16 days under aerobic conditions. Area 3 sediments are generally characterized by low pH and high nitrate levels (Brooks, 2001). Although chemical information for well FWB134 is unavailable, the nearest neighboring wells $(\sim 8-12 \mathrm{~m})$ display an average $\mathrm{pH}$ of $4.8 \pm 1.5$, and Area 3 sediments may contain greater than $2 \mu \mathrm{mol} / \mathrm{g} \mathrm{U}$ (Gu et al., 2005), 500 $\mu \mathrm{mol} / \mathrm{g} \mathrm{Fe}(\mathrm{III})$, and $1 \mathrm{mmol} / \mathrm{g} \mathrm{Al}(\mathrm{III})$ hydroxides (Wu et al., 2006a). Sediments were stored in the dark at $4^{\circ} \mathrm{C}$ for approximately 3 months prior to incubation, and sediment cores remained sealed for the duration of their storage. In each treatment, homogenized sediment (4 grams) was combined with sterile artificial groundwater $(250 \mathrm{~mL})$ buffered at either $\mathrm{pH} 5.5$ or 7.0 in sterilized $1 \mathrm{~L}$ erlenmeyer flasks. Incubation treatments included inositol hexaphosphate (Sigma Aldrich), glycerol (OmniPur) as the electron donor, and uranyl acetate (Spectrum) as follows: 10 $\mathrm{mM}$ phytate only; $10 \mathrm{mM}$ phytate and $10 \mathrm{mM}$ glycerol; $10 \mathrm{mM}$ phytate and $200 \mu \mathrm{M} \mathrm{U}(\mathrm{VI})$; or $10 \mathrm{mM}$ phytate, $10 \mathrm{mM}$ glycerol, and $200 \mu \mathrm{M} \mathrm{U}(\mathrm{VI})$. Glycerol was chosen as electron donor as it has been used successfully to stimulate the formation of uranium phosphate minerals by the ORFRC microbial communities (Beazley et al., 2011; Salome et al., 2013). In addition, pH 7.0 incubations were initially equilibrated with $10 \mathrm{mM} \mathrm{NaHCO}_{3}$ to reflect the composition of natural waters are circumneutral $\mathrm{pH}$ and inhibit schoepite precipitation. Although the phytate concentration used in the incubations was approximately two orders of magnitude higher than in 
118 typical soils (Turner, 2007), the concentration of uranium used was also high compared to the

119 field conditions in the $\mathrm{pH}$ range investigated $(\mathrm{Gu}$ et al., 2005). Reactors were maintained

120 aerobically in the dark by agitating unsealed flasks at $200 \mathrm{rpm}$ and $30{ }^{\circ} \mathrm{C}$ using a Lab-Line 3525

121 shaker incubator (Martinez et al., 2007). At each time point, part of a $1.5 \mathrm{~mL}$ filtered aliquot $(0.2$

$122 \mu \mathrm{m}$, PES Puradisc, Whatman) was preserved in $2 \%$ trace metal grade nitric acid for uranium

123 analysis, and the remainder was frozen $\left(-20^{\circ} \mathrm{C}\right)$ until analysis of inorganic phosphate $\left(\Sigma \mathrm{PO}_{4}{ }^{3-}\right)$

124 and inositol phosphates. Following incubation, sediments were collected and divided for

125 characterization by solid-phase sequential extraction, synchrotron X-ray diffraction spectroscopy

126 (XRD), and X-ray absorption spectroscopy (XAS). Samples for XAS were preserved at $-80^{\circ} \mathrm{C}$ in

$12750 \mathrm{~mL}$ centrifuge tubes until transport to the Stanford Synchrotron Radiation Lightsource

128 (SSRL). Just before analysis, the sediments were thawed, loaded into windowed Lexan sample

129 holders, and sealed with Kapton tape.

$130 \quad 2.3$ Analytical Techniques

131 Dissolved uranium was measured with an Agilent 7500a Series inductively-coupled

132 plasma mass spectrometer (ICP-MS) (Salome et al., 2013). To prevent the interference of 133 organophosphate compounds on conventional spectrophotometric techniques (Salome et al., 134 2013), total dissolved phosphate $\left(\mathrm{PPO}_{4}{ }^{3-}\right)$ was quantified by ion chromatography using a Dionex 135 GP-50 HPLC pump and conductivity detector (Dionex, CD-20) coupled to an Analytical 136 Instrument Systems, Inc. integrator (LCC 100). An anion exchange analytical column (Dionex 137 AS14, 4 x 250mm) and guard column (Dionex AG14, 4 x 50mm) were used in line with an 138 AMMS-300 (4-mm, Dionex) suppressor. The operating conditions included a $1 \mathrm{mM} \mathrm{NaHCO}$ 139 and $3 \mathrm{mM} \mathrm{Na}_{2} \mathrm{CO}_{3}$ buffer in $10 \%$ acetonitrile eluent with a $1 \mathrm{~mL} \mathrm{~min}^{-1}$ flow rate and a $25 \mathrm{mN}$ $140 \mathrm{H}_{2} \mathrm{SO}_{4}$ regenerant. Errors reported for uranium and phosphate measurements represent the 
141 standard deviation between triplicate incubations and the analytical error on duplicate 142 measurements. Inositol hexaphosphate ( $\left.\mathrm{IP}_{6}\right)$, inositol pentaphosphate (IP), inositol 143 tetraphosphate $\left(\mathrm{IP}_{4}\right)$, inositol triphosphate $\left(\mathrm{IP}_{3}\right)$, and inositol bisphosphate $\left(\mathrm{IP}_{2}\right)$ (standards from 144 Sigma Aldrich) were quantified using a modified chromatographic separation coupled to 145 suppressed spectrophotometric detection at $500 \mathrm{~nm}$ (Rounds and Nielsen, 1993) with a Dionex 146 ICS-3000 dual pump chromatography system. Separation was achieved with an OmniPac PAX147100 guard column $(4 \times 40 \mathrm{~mm})$, and eluent flow conditions included a 23 minute linear gradient 148 (0.5 mL/min) from $0.01 \mathrm{M}$ 1-methylpiperazine ( $\mathrm{pH} 4.0)$ to $0.38 \mathrm{M} \mathrm{NaNO}_{3}$ in $0.01 \mathrm{M} 1$ 149 methylpiperazine ( $\mathrm{pH} 4.0$ ). Following separation, $0.015 \%$ (w/v) $\mathrm{FeCl}_{3} \cdot 6 \mathrm{H}_{2} \mathrm{O}$ in $0.15 \%$ (w/v) 150 sulfosalicylic acid ( $\mathrm{pH} 1.8)$ was introduced $(0.5 \mathrm{~mL} / \mathrm{min})$ as post-column reagent through a 151 reaction coil to ensure thorough mixing. Complexation of the deep purple iron sulfosalicylate 152 complex by the phosphate groups on the inositol ring suppresses its absorption at $500 \mathrm{~nm}$ in a 153 proportion that is a function of the concentration of each inositol species. Reported errors for $\mathrm{IP}_{\mathrm{x}}$ $154(\mathrm{x}=1-6)$ species include analytical error and standard variation between triplicate incubations.

The solid phase speciation of uranium was quantified at the end of the incubation using a 156 modified sequential extraction technique (Tessier et al., 1979). The following procedure was 157 performed sequentially: (1) $1.0 \mathrm{M} \mathrm{MgCl}_{2}$ in $10 \mathrm{mM}$ nitrilotriacetic acid (NTA) (pH 4.5) was 158 added and agitated at $20^{\circ} \mathrm{C}$ for 1 hour to extract the loosely adsorbed fraction; (2) $1.0 \mathrm{M}$ acetic 159 acid ( $\mathrm{pH} 5.0)$ was added and agitated at $20^{\circ} \mathrm{C}$ for 5 hours to dissolve uranium minerals; (3) 0.04 $160 \mathrm{M} \mathrm{NH}_{2} \mathrm{OH} \cdot \mathrm{HCl}$ in $25 \%(\mathrm{v} / \mathrm{v})$ acetic acid was agitated at $96^{\circ} \mathrm{C}$ for 6 hours to remove $\mathrm{Fe}-$ and 161 Mn-associated uranium; (4) $1.5 \mathrm{~mL}$ of $0.02 \mathrm{M} \mathrm{HNO}_{3}$ and $2.5 \mathrm{~mL}$ of $30 \% \mathrm{H}_{2} \mathrm{O}_{2}(\mathrm{pH} 2.0)$ were 162 agitated at $96^{\circ} \mathrm{C}$ for 2 hours, a second $1.5 \mathrm{~mL}$ aliquot of $30 \% \mathrm{H}_{2} \mathrm{O}_{2}(\mathrm{pH} 2.0)$ was added and 163 agitated at $96^{\circ} \mathrm{C}$ for 3 hours, and a third $5 \mathrm{~mL}$ aliquot of $2.5 \mathrm{M} \mathrm{NH}_{4} \mathrm{OAc}$ in $20 \%$ (v/v) $\mathrm{HNO}_{3}$ 
164 was agitated at $20^{\circ} \mathrm{C}$ for 1 hour to extract the uranium fraction bound to organics; and (5) $15.8 \mathrm{M}$ $165 \mathrm{HNO}_{3}$ at $85^{\circ} \mathrm{C}$ was reacted for 3 hours to extract the residual fraction. After each extraction step, 166 samples were centrifuged, and supernatants were filtered (0.2 $\mu \mathrm{m}$, PES Puradisc Whatman) and 167 reserved for uranium analysis. Control experiments indicate recovery efficiencies of greater than $16880 \%$ for pure mineral phases (autunite) and uranium adsorbed onto lepidocrocite (not shown).

170 absorption (XAS) spectroscopy at the Stanford Synchrotron Radiation Lightsource (SSRL). 171 Unfortunately, no usable data was collected by synchrotron XRD as the concentration of 172 uranium in the sediments was too low to be detected. Uranium $\mathrm{L}_{\mathrm{III}}$-edge XAS spectra were 173 collected at SSRL beam line 4-1 using a focused X-ray beam with a $23 \mathrm{keV}$ harmonic rejection 174 cutoff and a 13 element Ge detector. The incident energy was selected with a $\operatorname{Si}(220)$ 175 monochromator crystal and data was collected using fluorescence detection. Extended X-ray 176 absorption fine structure (EXAFS) data for each incubation treatment was fitted using 177 SIXPACK (Webb, 2005), and phase and amplitude files for EXAFS fittings were created with 178 FEFF7 (Ankudinov et al., 1998; Zabinsky et al., 1995). The axial oxygen coordination number 179 (N) for all modeled treatments was set at two. Since the Debye-Waller factors $(\sigma)$ correlated 180 highly with coordination numbers $(\mathrm{N}), \sigma$ 's for some shells were each fixed at their average 181 values, and the $\mathrm{U}=\mathrm{O}_{\mathrm{ax}}=\mathrm{U}=\mathrm{O}_{\mathrm{ax}}$ transoxido multiple scattering path (Hudson et al., 1996) was 182 included in all fits. Due to the similar backscattering intensities and phases of $\mathrm{Mn}$ and Fe in 183 EXAFS, a "sum" of Fe/Mn like neighbors was reported for all treatments rather than distinct Fe 184 and Mn shells (Salome et al., 2013). 


\subsection{Abiotic Precipitation of Uranium and Phytate}

Equilibration of increasing concentrations of phytate with $200 \mu \mathrm{M}$ dissolved uranium revealed concentration-dependent uranyl solubilities at both $\mathrm{pH} 5.5$ and 7.0 (Figure 1B), likely due to the highly negative charge of phytate at both $\mathrm{pHs}$ (Figure $1 \mathrm{~A}$ ). At aqueous $\left[\mathrm{IP}_{6}\right]:[\mathrm{U}]$ ratios below 15:1, uranium formed precipitates with $\mathrm{IP}_{6}$ at both $\mathrm{pH} 5.5$ and 7.0 (Figure 1B). At or above $\left[\mathrm{IP}_{6}\right]:[\mathrm{U}]$ ratios of $15: 1$, however, uranium predominantly remained in solution at both $\mathrm{pHs}$

(Figure 1B). These results indicate that any artifact from the precipitation of uranium phytate complexes in the incubations should be avoided in excess phytate. Thus, $\mathrm{IP}_{6}$ concentrations of 10 $\mathrm{mM}$ were used in all the incubations conducted with $200 \mu \mathrm{M} \mathrm{U}(\mathrm{VI})$ to ensure that the abiotic 195 precipitation of uranium was minimized.

\subsection{Phytate Hydrolysis and Speciation during Sediment Slurry Incubations}

The $\mathrm{pH}$ of all reactors remained constant at the buffered $\mathrm{pH}$ for the duration of the incubations (data not shown). Interestingly, no inorganic phosphate was detected in any treatment at $\mathrm{pH} 7.0$ (Figure 2), and $\mathrm{IP}_{6}$ concentrations remained constant at $\sim 9 \mathrm{mM}$ for the duration of the experiments (Figure 3A-D). In contrast, all phytate-amended sediment slurry 201 incubations at pH 5.5 liberated inorganic phosphate, although at different rates and to different 202 extent depending on the treatment (Figure 2). In the absence of uranium, an 8 day difference in 203 lag phase for the initial release of extracellular phosphate was observed in $\mathrm{pH} 5.5$ reactors amended with both phytate and glycerol compared to identical reactors amended with phytate only (Figure 2). Once this initial limitation was overcome, however, inorganic phosphate was

206 liberated at a comparable net rate in reactors amended with phytate and glycerol $(20.5 \pm 5.1 \mathrm{mM}$

$\left.207 \mathrm{~d}^{-1}\right)$ and reactors amended with phytate but no external electron donor $\left(13.5 \pm 2.6 \mathrm{mM} \mathrm{d}^{-1}\right)($ Table 
208 1, Figure 2), suggesting similar organophosphate hydrolysis pathways in each of these 209 conditions. Surprisingly, the difference in lag phase for the onset of inorganic phosphate 210 production between $\mathrm{pH} 5.5$ phytate-amended reactors with and without glycerol was eliminated 211 upon introduction of $200 \mu \mathrm{M} \mathrm{U}(\mathrm{VI})$ (Figure 2). In fact, orthophosphate production in uranium212 amended reactors containing phytate but no exogenous electron donor began 2 days before 213 uranium-amended reactors containing both phytate and glycerol (Figure 2). In addition, net 214 orthophosphate production rates in $\mathrm{pH} 5.5$ reactors containing both phytate and uranium 215 decreased by more than threefold compared to identical reactors without uranium, regardless of 216 the presence $\left(5.6 \pm 0.4 \mathrm{mM} \mathrm{d}^{-1}\right)$ or absence $\left(4.6 \pm 0.3 \mathrm{mM} \mathrm{d}^{-1}\right)$ of external electron donor (Table 217 1, Figure 2).

As expected, the accumulation of aqueous orthophosphate at $\mathrm{pH} 5.5$ was coupled to 219 consumption of $\mathrm{IP}_{6}$ in both treatments (Figure 3A-B), confirming the existence of phytate220 metabolizing subsurface microorganisms at the ORFRC. However, in pH 5.5 reactors without 221 uranium, a lag phase of a few days was observed between the onset of phytate hydrolysis and the 222 accumulation of dissolved inorganic phosphate reactors amended with phytate (Figure 2 and 3A) 223 compared to reactors amended with both phytate and glycerol (Figure 2 and 3B). Despite 224 displaying similar orthophosphate production rates, the $\mathrm{IP}_{6}$ consumption rate in $\mathrm{pH} 5.5$ reactors 225 with phytate and glycerol, neglecting lag phases $\left(2.5 \pm 0.58 \mathrm{mM} \mathrm{d}^{-1}\right)$ (Table 1, Figure 3B), was 226 much higher than in identical reactors without exogenous electron donor $\left(0.92 \pm 0.22 \mathrm{mM} \mathrm{d}^{-1}\right)$ 227 (Table 1, Figure 3A). In addition, intermediate inositol phosphates did not accumulate 228 significantly in these conditions in the absence of uranium (Figure 3A-B) compared to similar 229 incubations conducted in the presence of uranium, which displayed successive accumulation of $230 \mathrm{IP}_{5}, \mathrm{IP}_{4}$, and $\mathrm{IP}_{3}$ in various concentrations depending on the presence of external electron donor 
231 (Figure 3C-D). Finally, neglecting any lag phases, $\mathrm{IP}_{6}$ consumption rates in $\mathrm{pH} 5.5$ reactors

232 amended with uranium and phytate apparently doubled $\left(1.7 \pm 0.38 \mathrm{mM} \mathrm{d}^{-1}\right)$ compared to

233 identical reactors without uranium $\left(0.92 \pm 0.22 \mathrm{mM} \mathrm{d}^{-1}\right)($ Table 1 , Figure $3 \mathrm{~A}$ and C), while IP 6

234 consumption rates in $\mathrm{pH} 5.5$ reactors amended wit uranium, phytate, and glycerol $(2.9 \pm 0.21$

$\left.235 \mathrm{mM} \mathrm{d}^{-1}\right)$ were comparable to identical reactors without uranium $\left(2.5 \pm 0.58 \mathrm{mM} \mathrm{d}^{-1}\right)($ Table 1 ,

236 Figure 3B and D). The differences between IP6 consumption rates without glycerol should

237 considered carefully, however, as the temporal resolution of the IP6 measurements in the

238 treatment without uranium was not high enough in the period of consumption to determine rates

239 with high accuracy.

240

\subsection{Transformation of Uranium during Sediment Slurry Incubations}

241 Importantly, uranium was not released from Area 3 sediments in incubations amended with

242 phytate but not uranium (data not shown), suggesting both a lack of ligand-mediated dissolution

243 of uranium minerals and desorption of sorbed uranium species. Although $200 \mu \mathrm{M} U(\mathrm{VI})$ was

244 introduced into each uranium-amended reactor, significantly less dissolved uranium was

245 measured within minutes after inoculation. Only $60 \mu \mathrm{M}$ aqueous uranium was detected after 30

246 minutes in the $\mathrm{pH} 5.5$ incubations without phytate, whereas $110 \mu \mathrm{M}$ was detected in $\mathrm{pH} 5.5$

247 reactors amended with phytate (Figure 4A). Uranium concentrations in controlled incubations

248 (i.e., no glycerol or phytate) at pH 5.5 decreased only slightly from their initial values over the

249 first 8 days (Figure 4A), suggesting that uranium sorption was initially fast but incomplete. In

250 contrast, $97 \%$ of the initial aqueous uranium was removed from solution by day 8 in $\mathrm{pH} 5.5$

251 incubations containing phytate, regardless of the presence of electron donor (Figure 4A).

252 Concurrently, relatively low concentrations of inorganic phosphate were produced in solution

253 during the first week of the incubations with phytate, irrespective of the presence of electron 
254 donor (Figure 4B). In pH 7.0 reactors amended with $200 \mu \mathrm{M} \mathrm{U}(\mathrm{VI})$, aqueous uranium 255 concentrations averaged $\sim 130 \mu \mathrm{M}$ initially and were not significantly affected by the presence or 256 absence of phytate (Figure 4A). After the initial sampling point, however, aqueous uranium in $257 \mathrm{pH} 7.0$ reactors without phytate rapidly decreased to $2 \mu \mathrm{M}$, whereas dissolved uranium in $\mathrm{pH} 7.0$ 258 reactors amended with both uranium and phytate gradually decreased from $130 \mu \mathrm{M}$ to $70 \mu \mathrm{M}$ 259 over the duration of the incubations (Figure 4A). The behavior of dissolved uranium in the 260 incubations amended with glycerol, phytate, and uranium mirrored that of the incubations 261 conducted without exogenous electron donor, albeit in slightly higher concentrations (Figure 262 4A). The drastic drop in aqueous uranium concentration in $\mathrm{pH} 7.0$ reactors without phytate was 263 followed at day 5 by a brief remobilization and gradual removal down to $2 \mu \mathrm{M}$ by the end of the 264 incubations (Figure 4A).

\section{3.4 Solid-phase Uranium Characterization}

Although sequential extractions of ORFRC sediments incubated at $\mathrm{pH} 5.5$ and 7.0 in the

267 presence of elevated uranium concentrations generally provided high uranium recoveries, they

268 were slightly better at $\mathrm{pH} 5.5$ than $\mathrm{pH} 7.0$ (Figure 5). These extractions revealed a significant 269 shift in solid-phase uranium speciation between slurries with and without phytate. Without 270 phytate, uranium was primarily associated with $\mathrm{Mg}^{2+}$ exchangeable, acetate extractable, and 271 hydroxylamine extractable fractions at both $\mathrm{pH} 5.5$ (Figure 5A) and 7.0 (Figure 5B). In turn, 272 solid-phase uranium speciation shifted towards the more recalcitrant hydroxylamine extractable 273 and peroxide extractable fractions upon introduction of phytate at both pHs (Figure 5). Solid274 phase extractions also revealed that $50 \%$ of uranium was strongly adsorbed (i.e., hydroxylamine 275 extractable) at $\mathrm{pH} 7.0$ in the presence of phytate (Figure 5B) compared to only $30 \%$ at $\mathrm{pH} 5.5$ 276 (Figure 5A). Simultaneously, 35\% of uranium was found in the peroxide extractable fraction of 
277 the $\mathrm{pH} 7.0$ incubations with little or no phytate hydrolysis (Figure 5B), whereas 60\% of uranium 278 was extracted by peroxide in $\mathrm{pH} 5.5$ incubations.

279 Examination of solid-phase uranium by XANES revealed a uranium $\mathrm{L}_{\text {III }}$-edge at $\sim 17163$ $280 \mathrm{eV}$ and a characteristic U(VI) shoulder between 17187 and $17200 \mathrm{eV}$ in all treatments (Figure $2816 \mathrm{~A}$ ), confirming that uranium existed as $\mathrm{U}(\mathrm{VI})$ in these aerobic incubations. Additionally, the

$282 \mathrm{k}^{3}$-weighted EXAFS fittings confirmed the presence of an axial oxygen shell at $1.80 \AA$ in all 283 incubations (Figure 6B-C, Table 2). Split equatorial oxygen shells at $2.25 \AA$ and $2.41 \AA$ were 284 required to improve EXAFS fittings in uranium-amended reactors without phytate at both $\mathrm{pH}$ 285 (Table 2). However, only a single equatorial oxygen shell was required to improve the fit of 286 uranium-amended reactors in the presence of phytate at both $\mathrm{pH}$, regardless of the presence of 287 external electron donor (Table 2). In turn, the inclusion of Mn or Fe EXAFS shells was required 288 for all treatments (Figure 5, Table 2), suggesting a close interaction between uranium and 289 manganese and iron oxides. Although phosphorus shells improved EXAFS fittings of pH 5.5 290 uranium-amended reactors with phytate, in which significant inorganic phosphate was produced 291 (Figure 6B and C), a P-shell was not required to improve EXAFS fittings of solids from the $\mathrm{pH}$ 2927.0 phytate-amended incubations (Table 2). Finally, a C-shell was required to improve the 293 fittings of the incubations conducted at $\mathrm{pH}$ 7.0, reflective of the addition of dissolved inorganic 294 carbon (DIC) to buffer the $\mathrm{pH}$.

\subsection{DISCUSSION}

296 4.1 Solubility of Uranium in the Presence of Phytate

In natural waters (pH 2-10), phytate carries a highly negative charge of between -6 and -9

298 (Figure 1A) and, thus, is expected to interact strongly with positively charged uranyl hydroxide 
complexes at or below circumneutral $\mathrm{pH}$, providing carbonates are not present in significant concentrations (Turner et al., 2002). Accordingly, the apparent concentration-dependent solubility of uranyl in the presence of phytate at both $\mathrm{pH} 5.5$ and 7.0 (Figure 1B) was likely caused by the interaction of the positively charged uranyl ion with negatively charged $\mathrm{IP}_{6}($ Figure 1A). Although uranium precipitated with $\mathrm{IP}_{6}$ at aqueous [ $\left.\mathrm{IP}_{6}\right]:[\mathrm{U}]$ ratios below 15:1, uranium primarily remained in solution when phytate concentrations increased to or above $3 \mathrm{mM}$ ([IP $]:[U] \geq 15: 1)$. Previous studies have demonstrated similar concentration-dependent uranyl solubility in the presence of other organophosphates (Beazley et al., 2007), and the increase in uranium solubility with elevated phytate concentration is thought to be caused by enhanced electronic repulsion as the negatively charged phytate concentration increases around the uranium phytate complex. These findings have important implications for the promotion of $\mathrm{U}(\mathrm{VI})$-phosphate biomineralization by phytate, as the $\left[\mathrm{IP}_{6}\right]$ :[U] ratio likely determines whether a chemical (i.e., adsorption of $\mathrm{U}(\mathrm{VI})$ at low concentrations of phytate) or biological (i.e., biomineralization of U(VI) phosphate minerals at high concentrations of phytate) sequestration process dominates.

\subsection{Phytate Degradation during the Sediment Incubations}

Inorganic phosphate was produced in all $\mathrm{pH} 5.5$ incubations amended with phytate (Figure 2). However, the rate and extent of the net release of phosphate in solution varied according to the slurry treatment (Figure 2). If phytate degradation resulted from chemical hydrolysis, no differences in phosphate production should be observed in incubations amended with glycerol and/or uranium compared to their unamended controls. These characteristic differences in orthophosphate production, therefore, suggest that phytate degradation likely resulted from biologically-mediated phytate hydrolysis, possibly induced by phosphate starvation 
322 conditions (Mukhametzyanova et al., 2012). Although these findings have to be confirmed, the

323 phytases involved are likely acid phytases, which are typically activated between $\mathrm{pH} 2.0$ and 6.0

324 (Rao et al., 2009). In contrast, pH 7.0 reactors did not produce inorganic phosphate (Figure 2),

325 and $90 \%$ of the $\mathrm{IP}_{6}$ added to the reactors remained in solution over the duration of the

326 incubations (Figure 3A-D). Phytate adsorbs strongly to iron oxides at this pH (Degroot and

327 Golterman, 1993; Johnson et al., 2012), suggesting that 10\% phytate ( $1 \mathrm{mM})$ was removed by

328 adsorption onto ORFRC sediments. At such high concentration, phytate should also outcompete

329 inorganic phosphate for sediment sorption sites (Degroot and Golterman, 1993). Thus, the lack

330 of inorganic phosphate in solution suggest either that the small fraction of inorganic phosphate

331 produced during phytate hydrolysis may have been consumed by incorporation into biomass or

332 that phytate hydrolysis at $\mathrm{pH} 7.0$ did not occur due to the absence of organisms carrying alkaline

333 phytases or to a calcium limitation, as calcium is required for alkaline phytase activity (Ha et al.,

334 2000). In any case, the lack of significant phytate hydrolysis at $\mathrm{pH} 7.0$ suggests that phytate

335 hydrolysis by the ORFRC natural microbial community is highly sensitive to subsurface

336 geochemical conditions (i.e., $\mathrm{pH}, \mathrm{Ca}^{2+}$ ), which is not surprising as phytase enzymes active at

337 acidic, circumneutral, and/or alkaline $\mathrm{pH}$ are expressed by different genes and display different

338 catalytic mechanisms (Oh et al., 2004).

An eight day difference in lag phase for the initial release of extracellular phosphate was

340 observed in $\mathrm{pH} 5.5$ reactors amended with phytate and glycerol but no uranium compared to

341 identical reactors amended with phytate only (Figure 2). As only endogenous electron donors

342 were available in incubations that did not receive uranium or glycerol amendments, this lag

343 phase suggests that the activity of the natural microbial community was limited by electron

344 donor availability resulting in delayed phytate mineralization. The onset of phytate hydrolysis 
345 and orthophosphate accumulation was also delayed in reactors without uranium or glycerol

346 (Figure 2 and 3A) relative to identical treatments with glycerol (Figure 2 and 3B), suggesting

347 that sorption of phosphate to ORFRC sediments in the glycerol-amended incubations was limited

348 by competitive sorption of glycerol (Liu et al., 2009; Violante and Pigna, 2002). In addition, the

349 accumulation of inositol intermediates $\left(\mathrm{IP}_{2}-\mathrm{IP}_{5}\right)$ was not evident in any of these reactors,

350 regardless of the presence of external electron donor (Figure 3A-B), and mass balance

351 calculations indicate that the sole inositol phosphate species not analyzed ( $\left.\mathrm{IP}_{1}\right)$ did not constitute

352 a significant fraction of inositol phosphate intermediates in these incubations (1-12\% of total P).

353 Although $\mathrm{IP}_{6}$ hydrolysis requires catalysis by phytase enzymes above $\mathrm{pH} 1$ (Irving and

354 Cosgrove, 1974), hydrolysis of lower inositol phosphates may be catalyzed by phytase enzymes

355 and/or non-specific phosphomonoesterase (phosphatase) enzymes (Turner et al., 2002). These

356 considerations suggest that $\mathrm{IP}_{6}$ to $\mathrm{IP}_{5}$ conversion by phytase enzymes could also have initiated

357 glycerol-independent non-specific phosphatase enzyme production that facilitated 358 dephosphorylation of intermediate inositol phosphate species.

Previous studies have proposed that microbial phosphatases are overexpressed in contaminated environments as detoxification mechanism resulting from exposure to heavy 361 metals (Macaskie et al., 1994; Montgomery et al., 1995; Powers et al., 2002; Sobecky et al., 362 1996; Yong and Macaskie, 1995). The disparity in the lag phase of inorganic phosphate 363 production between $\mathrm{pH} 5.5$ phytate-amended reactors with and without glycerol was not only 364 eliminated, but unexpectedly reversed in the presence of $200 \mu \mathrm{M}$ U(VI) (Figure 2). In addition, $365 \mathrm{IP}_{6}$ consumption rates apparently doubled $\left(1.7 \pm 0.38 \mathrm{mM} \mathrm{d}^{-1}\right)$ in $\mathrm{pH} 5.5$ uranium-amended 366 reactors with phytate but no glycerol compared to identical reactors without uranium $(0.92 \pm$ $3670.22 \mathrm{mM} \mathrm{d}^{-1}$ ) (Table 1, Figure 3A and $\mathrm{C}$ ), while these rates were comparable in uranium- 
368 amended reactors with phytate and glycerol $\left(2.9 \pm 0.21 \mathrm{mM} \mathrm{d}^{-1}\right)$ compared to identical reactors 369 without uranium $\left(2.5 \pm 0.58 \mathrm{mM} \mathrm{d}^{-1}\right)$ (Table 1, Figure 3B and D). As divalent cations 370 advertently affect the activity of acid phytases (Oh et al., 2004), uranyl was likely not directly 371 responsible for the increase in phytate hydrolysis. The increase in $\mathrm{IP}_{6}$ consumption rate 372 combined with the disappearance of the lag phase for the onset of orthophosphate production 373 upon uranium addition, therefore, suggest that microbial communities may have responded to 374 uranium stress by expressing phytase enzymes. Indeed, previous studies have demonstrated 375 upregulation of phytase genes by Caulobacter crescentus exposed to uranium stress (Hu et al., 376 2005; Yung et al., 2014). The apparent increase in phytate hydrolysis by ORFRC 377 microorganisms in the presence of glycerol but no uranium, however, indicates that electron 378 donor limitation may also affect bacterial phytate metabolism.

The threefold decrease in net orthophosphate production rates in $\mathrm{pH} 5.5$ reactors 380 containing both phytate and uranium compared to identical reactors without uranium, regardless 381 of the presence of external electron donor (Figure 2), was probably due to an alteration of the 382 kinetics of hydrolysis of $\mathrm{IP}_{5}$ through $\mathrm{IP}_{2}$ in the presence of uranium as evidenced by the 383 significant accumulation of intermediate inositol phosphates in these conditions (Figure 3C-D) 384 compared to identical incubations without uranium (Figure 3A-B). The decreased 385 transformation rates of the intermediate inositol phosphates in the presence of uranium at $\mathrm{pH} 5.5$ 386 suggest an apparent uranium toxicity effect on the ORFRC microbial community expressed 387 either through the inhibition of phosphatase production and/or activity or through a shift in the 388 dominant enzyme catalyzing $\mathrm{IP}_{\mathrm{x}}(\mathrm{x}=1-5)$ hydrolysis from phosphatase to phytase. Given the complexity of the production and consumption kinetics of intermediate inositol phosphates, it is 
390 difficult to distinguish between these two possible explanations for the observed decrease in $\mathrm{IP}_{\mathrm{x}}$

$391 \quad(x=2-5)$ transformation rates.

\subsection{Fate of Uranium during the Sediment Incubations}

In all uranium amended reactors, measured uranium concentrations decreased significantly from the initially added $200 \mu \mathrm{M}$ within minutes after inoculation (Figure 4A). In

395 contrast to the the $\mathrm{pH} 7.0$ incubations which displayed similar dissolved uranium concentrations 396 initially, the presence of excess phytate in the $\mathrm{pH} 5.5$ incubations resulted in a much higher 397 initial dissolved uranium concentration than in controlled incubations without phytate. These 398 results can be explained partly because uranium solubility is enhanced by the formation of 399 uranium phytate complexes at both pHs (Figure 1B) and partly because the abundance of 400 negatively charged surface groups on the iron oxides at circumneutral $\mathrm{pH}$ prevents significant 401 adsorption of the negatively charged uranyl phytate or carbonate complexes at $\mathrm{pH} 7.0$ 402 (Katsoyiannis, 2007). In addition, as phytate is highly negatively charged at $\mathrm{pH}>2$ (Figure 1A) 403 and adsorbs strongly and irreversibly to iron oxides (Degroot and Golterman, 1993; Johnson et 404 al., 2012) and other natural sorbents (e.g., aluminosilicates), the apparent sorption of $\sim 1 \mathrm{mM}$ 405 phytate before uranium addition (Figure 3A-D) may have provided an additional mechanism to 406 prevent adsorption of uranium onto the solid phase.

More importantly, the significant decrease in dissolved uranium ( 97\%) during the first 408 week of the $\mathrm{pH} 5.5$ incubations amended with phytate regardless of the presence of external 409 electron donor (Figure 4A) along with the relatively low concentrations of orthophosphate 410 accumulated in solution (Figure 4B) suggest that inorganic phosphate likely contributed to 411 uranium removal from solution through formation of stable U(VI)-phosphate minerals (Beazley 
412 et al., 2007; Beazley et al., 2011; Paterson-Beedle et al., 2010; Shelobolina et al., 2009), though

413 the precipitation of U(VI)-IP ${ }_{x}(x=1-6)$ minerals (Knox et al., 2008; Nash et al., 1998; Seaman et

414 al., 2003), which may be further transformed to U(VI)-phosphate minerals (Nash et al., 1998),

415 may have also contributed to uranium removal in these incubations. Thermodynamic

416 equilibrium calculations (Table 3) indeed predict that $100 \%$ of uranium should be precipitated as

417 autunite at $\mathrm{pH} 5.5$ given the degree of orthophosphate production and absence of carbonates in

418 this system. In contrast, the gradual and incomplete decrease in dissolved uranium concentration

419 in the phytate-amended incubations at $\mathrm{pH} 7.0$ regardless of the presence of external electron

420 donor (Figure 4A), combined with the lack of phytate hydrolysis in these conditions (Figure 2

421 and 3A-D), indicate the formation of aqueous $\mathrm{U}(\mathrm{VI})$-phytate complexes increases uranium

422 solubility by inhibiting uranium adsorption to ORFRC sediments. The lack of carbonates in the

$423 \mathrm{pH} 5.5$ incubations does not prevent comparison of these two sets of incubations, as carbonates

424 should have little impact of $\mathrm{U}(\mathrm{VI})$ speciation at $\mathrm{pH} 5.5$ given their low concentrations and

425 weaker complexing properties with metals compared to phytate (Crea et al., 2008; Cigala et al.,

426 2011). Considering the complete removal of uranium from solution during the first 24 hours in

427 the absence of phytate but presence of carbonates at $\mathrm{pH} 7.0$ (Figure 4A), these findings suggest

428 that the presence of phytate also prevents sequestration of uranium via schoepite precipitation.

429 Overall, the enhanced removal of dissolved uranium in phytate-amended reactors at $\mathrm{pH} 5.5$,

430 which display significant inorganic phosphate production from $\mathrm{IP}_{6}$ hydrolysis compared to

431 identical reactors at $\mathrm{pH}$ 7.0, demonstrates the efficiency of U(VI)-phosphate biomineralization

432 promoted by phytate hydrolysis in low pH ORFRC sediments.

The solid phase extraction and XAS data obtained from the sediment at the end of the

434 incubations can be combined with the dissolved uranium concentrations to identify the fate of 
435 uranium in the solid phase. The apparent shift in solid-phase uranium speciation from the 436 magnesium and acetate fractions in the initial sediment to the hydroxylamine and peroxide 437 fractions in the sediment incubated in the presence or absence of phytate at both pH 5.5 and 7.0 438 (Figure 5) indicates that phytate addition triggers a change in the dominant uranium removal 439 mechanism, regardless of the presence or absence of carbonates, even when inorganic phosphate 440 is not produced. Previous studies investigating U(VI)-phosphate biomineralization also 441 demonstrated significant hydroxylamine-extractable uranium in Oak Ridge sediments 442 containing U(VI)-phosphate precipitates attributable either to the presence of strongly sorbed $443 \mathrm{U}(\mathrm{VI})$ or $\mathrm{U}(\mathrm{VI})$-phosphate precipitates incorporated into iron oxides (Beazley et al., 2011; 444 Salome et al., 2013). In the present incubations, the initial adsorption of both phytate (Figure 3) 445 and uranium (Figure 4 ) indicates that ternary $=\mathrm{Fe}-\mathrm{IP}_{6}-\mathrm{UO}_{2}{ }^{2+}$ surface complexes may have 446 contributed significantly to the hydroxylamine-extractable uranium fraction quantified at the end 447 of the incubations. In addition, chemical control experiments (data not shown) indicate that $448 \mathrm{U}(\mathrm{VI})-\mathrm{IP}_{\mathrm{x}}(\mathrm{x}=2-6)$ precipitates constitute the majority of the observed peroxide-extractable 449 uranium fraction in these experiments. Comparison of dissolved uranium data in the phytate-amended incubations (Figure 4) 451 reveals that $40 \%$ more uranium was removed in $\mathrm{pH} 5.5$ incubations that released $40 \mathrm{mM}$ 452 inorganic phosphate than in the $\mathrm{pH} 7.0$ incubations that did not produce orthophosphate. The 453 additional uranium removed at $\mathrm{pH} 5.5$ can be attributed to a mechanism other than adsorption 454 and/or diffusion of uranium into the crystal lattice of mineral phases. The fraction of strongly 455 adsorbed (i.e. hydroxylamine extractable) uranium was higher while the fraction of uranium 456 associated with the peroxide extractable fraction was lower in $\mathrm{pH} 7.0$ incubations amended with 457 phytate compared to otherwise identical incubations at $\mathrm{pH} 5.5$ (Figure 5). If the removal of 
uranium was mainly due to the formation of $\mathrm{U}_{-} \mathrm{IP}_{6}$ precipitates, the peroxide extractable fraction of uranium should be similar at $\mathrm{pH} 5.5$ and 7.0 given the highly negative charge on $\mathrm{IP}_{6}$ at both pHs (Figure 1A). These observations, therefore, suggest that approximately $35 \%$ of uranium was chemically precipitated with $\mathrm{IP}_{6}$ at $\mathrm{pH} 7.0$ (Figure 5B), while $70 \%$ of uranium was precipitated as a mixture of $\mathrm{U}-\mathrm{IP}_{\mathrm{x}}(\mathrm{x}=2-6)$ and $\mathrm{U}(\mathrm{VI})-\mathrm{PO}_{4}{ }^{3-}$ minerals at $\mathrm{pH} 5.5$ (Figure 5A).

The presence of solid-phase associated U(VI) was confirmed by examination of solidphase uranium by XANES. Concurrently, the split equatorial oxygen shells at $2.25 \AA$ and $2.41 \AA$ required to improve EXAFS fittings in uranium-amended reactors without phytate at both $\mathrm{pH}$ (Table 2) may indicate the presence of schoepite (Allen et al., 1996) or U(VI) ternary surface complexes on iron or manganese oxides with carbonates or other complexing ligands (Waite et al., 1994; Webb et al., 2006) in agreement with the rapid ( $<24$ hours) removal of dissolved uranium observed at both pHs (Figure 4A). Rather than the split equatorial shells observed in reactors without phytate, only a single equatorial oxygen shell was required to improve the fit of uranium-amended reactors in the presence of phytate at both pHs (Table 2). These findings indicate the presence of phytate may drive a shift in the dominant uranium removal mechanism between these treatments from surface-mediated ternary complex formation to solution-mediated precipitation reactions, even when no phytate hydrolysis occurs. This shift in removal mechanism is also reflected by the shift in solid-phase speciation between $\mathrm{pH} 7.0$ reactors with and without phytate determined by sequential extractions (Figure 5B). Despite the presence of significant $\mathrm{Al}(\mathrm{III})$ hydroxides in Area 3 sediments (Wu et al., 2006a), past studies have demonstrated particulate uranium to be associated primarily with iron oxides, mixed manganese and iron oxides, and phosphate precipitates (Stubbs et al., 2006; Wu et al., 2006a). The required inclusion of Mn or Fe but not Al EXAFS shells in all treatments seems to confirm that sorption 
481 to manganese or iron oxides represents a prevalent uranium sink in this system (Figure 5, Table

482 3), even in phytate-amended reactors where precipitation of U-phosphate phases is important.

483 The required inclusion of phosphorus shells to improve the EXAFS fittings of $\mathrm{pH} 5.5$ uranium-

484 amended reactors with phytate (Table 2) suggests that solid-phase uranium in $\mathrm{pH} 5.5$ reactors

485 was likely associated with phosphate through a combination of ternary $=\mathrm{Fe}-\mathrm{IP}_{6}-\mathrm{UO}_{2}{ }^{2+}$ surface

486 complexes, U(VI)-phosphate precipitates, and U(VI)-phytate precipitates. For pH 7.0 reactors,

487 however, addition of a phosphorus shell did not improve the fit (Table 2), indicating that U(VI)-

$488 \mathrm{IP}_{6}$ precipitates may not represent the dominant form of solid $\mathrm{U}$ at this $\mathrm{pH}$. Likely, both uranium

489 sorption to ORFRC sediments and precipitation of schoepite contributed to uranium removal in 490 the $\mathrm{pH} 7.0$ incubations.

\subsection{Environmental Implications}

These findings have important environmental implications. First, the biomineralization of

$495 \mathrm{U}(\mathrm{VI})$ phosphates has been proposed to represent a detoxification mechanism for 496 microorganisms present in uranium-contaminated environments. As these environments are 497 often associated with acidic $\mathrm{pHs}$ as a result of the presence of nitric acid used to extract uranium 498 from ore, it appears logical that acid phytases but not alkaline phytases are activated by the 499 presence of uranium. Second, as the hydrolysis of phytate by phytases generates intermediate 500 inositol phosphate species that can be degraded by natural phosphatases (Turner et al., 2002), it 501 is possible that a diverse microbial community may be stimulated by the hydrolysis of phytate. 502 Although the present study reveals that uranium alters the overall hydrolysis of phytate 
503 compared to similar incubations without uranium, the generation of vast concentrations of 504 inorganic phosphate in solution may be able to locally remediate the uranium problem and 505 simultaneously help the microbial community recover after removal of uranium via precipitation 506 of U(VI)-phosphate minerals. The production of large excess inorganic phosphate compared to 507 uranium concentrations in these incubations also indicates that phytate hydrolysis is efficient and 508 suggests that the natural phytate concentration of soils may be sufficient to promote the 509 biomineralization of uranium.

510 Simultaneously, the results of this study may have important ramifications for the 511 bioremediation of uranium-contaminated environments. Although bioreduction has been 512 extensively studied as a uranium bioremediation technique, the instability of the uraninite 513 mineral product, particularly in fluctuating redox environments, warrants investigation of 514 alternative uranium immobilization strategies. The biomineralization of U(VI)-phosphate 515 minerals may represent an appealing remediation technique for in situ uranium immobilization as 516 it may occur in both aerobic (Beazley et al., 2007; Macaskie et al., 1995; Martinez et al., 2007; 517 Montgomery et al., 1995; Shelobolina et al., 2009) and anaerobic conditions (Beazley et al., 518 2009; Shelobolina et al., 2009) as well as in elevated nitrate and low pH conditions (Beazley et 519 al., 2011; Salome et al., 2013) where bioreduction is not favorable (Belli and Taillefert, 2016). 520 Thus far, U(VI)-phosphate biomineralization has primarily been demonstrated using synthetic 521 organophosphate sources such as glycerol-2-phosphate. Utilizing phytate in uranium 522 bioremediation strategies may present several advantages over previously studied compounds.

523 First, phytate, a naturally occurring organophosphate in surface soils, may potentially yields six 524 moles of orthophosphate per mole of phytate and promote the natural attenuation of uranium 525 contaminations via the biomineralization of uranium phosphate minerals. Second, phytate can be 
526 purified inexpensively from wheat products (Abebe et al., 2007) if exogenous sources are

527 required for bioremediation. Third, as the microbial community hydrolyzed the majority of the

528 high phytate concentrations used in the incubations, phytate amendments could be optimized in

529 bioremediation strategies to maximize the coverage of the contaminated area while

530 simultaneously keeping production of the potential contaminant by-product orthophosphate to a

531 minimum. Fourth, the lower net rates of transformation of inositol phosphate intermediates and

532 the slower kinetics of production of inorganic phosphate in the presence of elevated uranium

533 could allow time for phytate and its inositol phosphate intermediates to migrate within

534 contaminant plumes before hydrolysis occurs and, thus, increase the remediated surface area.

535 Fifth, while phytate sorption may limit its transport, sorbed $\mathrm{IP}_{6}$ may also represent a long term

536 source of inorganic phosphate to contaminated environments. Finally, phytate may chemically

537 precipitate with uranium (Knox et al., 2008; Nash et al., 1998; Seaman et al., 2003) depending on

538 its concentration (Figure 1), further decreasing aqueous uranium concentrations. As phytate

539 hydrolysis results in the precipitation of uranium, previous concerns over increased uranium

540 mobility in contaminated sediments upon phytate amendment (Seaman et al., 2003) seem to be

541 unfounded. In turn, two important aspects have to be considered before phytate amendments can

542 be made in contaminated environments. First, uranium solubility may be enhanced at

543 circumneutral $\mathrm{pH}$ in the presence of elevated concentrations of phytate if phytate hydrolysis does

544 not occur, regardless of the concentration of DIC (Figure 1). Although phytase enzymes are

545 commonly found in soils and aquatic systems (Jorquera et al., 2008; Lim et al., 2007),

546 preliminary studies must be conducted to ensure the indigenous microbial community of a

547 particular contaminated subsurface expresses phytase enzymes in geochemical conditions

548 representative of that site. Second, the U(VI)-phosphate by-product may be destabilized by 
549 carbonates at circumneutral $\mathrm{pH}$ if their concentrations are high enough. Although U(VI)-

550 phosphate minerals are found in a wide variety of soils (Sato et al. 1997), including those in the

551 DOE sites in Oak Ridge, TN (Roh et al. 2000) and Hanford, WA (Arai et al. 2007) and the

552 former Fernald Environmental Management Project site in Fernald, OH (Morris et al. 1996),

553 such strategy may therefore be better suited for low $\mathrm{pH}$ environments where the influence of

554 carbonates is minimized.

\subsection{CONCLUSIONS}

The large volume of uranium-contaminated groundwater and soils at DOE facilities

557 across the United States warrants the development of creative in situ remediation techniques that

558 are able to immobilize uranium in the solid phase over large areas. In this study, the

559 biomineralization of U(VI)-phosphate minerals promoted by the addition of phytate, a natural

560 organophosphate compound found in soils, was demonstrated in uranium-contaminated

561 sediments of the ORFRC. To our knowledge, this is the first study investigating U(VI)-

562 phosphate biomineralization promoted by phytate hydrolysis. The hydrolysis of phytate with the

563 concomitant release of inorganic phosphate by indigenous subsurface microorganisms of

564 ORFRC sediments occurred at low $\mathrm{pH}$ and was enhanced in the presence of uranium, likely as a

565 response to uranium toxicity. At the same time, uranium stress decreased hydrolysis of

566 intermediate inositol phosphate species and promoted the immobilization of uranium via ternary

$567=\mathrm{Fe}-\mathrm{IP}_{6}-\mathrm{UO}_{2}{ }^{2+}$ surface complex formation, precipitation of U(VI)-phytate minerals, and

568 biomineralization of $\mathrm{U}(\mathrm{VI})$-phosphate minerals. Interestingly, phytate hydrolysis was not

569 observed in $\mathrm{pH} 7.0$ incubations, suggesting that alkaline phytase was not produced by native

570 ORFRC microorganisms or that calcium concentrations were not sufficient to support the

571 activity of alkaline phytase. These findings have important environmental implications. First, 
572 the abundance of plant-derived phytate in soils may promote the natural attenuation of uranium

573 contaminations via the biomineralization of uranium phosphate minerals. Second, if the

574 biomineralization of $\mathrm{U}(\mathrm{VI})$ phosphates acts as a detoxification mechanism for microorganisms,

575 the large phosphate concentrations generated by phytate hydrolysis may be able to help the

576 natural microbial community recover from any effects of the presence of uranium after U(VI)-

577 phosphate precipitation. Third, promoting the biomineralization of U(VI)-phosphate minerals

578 using phytate as organophosphate source may represent an inexpensive bioremediation

579 alternative as phytate is easily extracted from wheat products and generates much higher

580 concentrations of inorganic phosphates compared to other organophosphate compounds

581 investigated for such applications. Fourth, although the hydrolysis of lower inositol derivatives

582 by conventional phosphohydrolases may be affected by the presence of uranium, the slow

583 hydrolysis of phytate and its inositol phosphate intermediates in the presence of uranium may

584 facilitate its spreading over large surface areas and provide a long-term source of inorganic

585 phosphorus. Finally, phytate may abiotically precipitate uranium and, therefore, does not always

586 require phytases to be efficient. To determine the exact effect of uranium on the phytate-

587 hydrolyzing microbial community and to elucidate the mechanism of phytate-hydrolysis by this

588 community, however, pure cultures should be isolated. As ORFRC groundwater may be highly

589 acidic with fluctuating redox conditions, the ability of the natural microbial community to 590 hydrolyze phytate at lower $\mathrm{pH}$ or in nitrate-reducing conditions should also be examined.

\section{ACKNOWLEDGEMENTS}


595 Radiation Lightsource, a national user facility operated by Stanford University on behalf of the 596 US DOE, Office of Basic Energy Sciences. We thank Dave Watson of Oak Ridge National 597 Laboratory for providing ORFRC sediment cores. We also thank the Associated Editor and four 598 anonymous reviewers for their constructive suggestions to improve this paper. 


\section{References}

Abebe, Y., Bogale, A., Hambidge, K.M., Stoecker, B.J., Bailey, K. and Gibson, R.S. (2007) Phytate, zinc, iron and calcium content of selected raw and prepared foods consumed in rural Sidama, Southern Ethiopia, and implications for bioavailability. J. Food Comp. Anal. 20, 161-168.

Alessi, D.S., Lezama-Pacheco, J.S., Stubbs, J.E., Janousch, M., Bargar, J.R., Persson, P. and Bernier-Latmani, R. (2014) The product of microbial uranium reduction includes multiple species with U(IV)-phosphate coordination. Geochim. Cosmochim. Acta 131, 115-127.

Allen, P.G., Shuh, D.K., Bucher, J.J., Edelstein, N.M., Palmer, C.E.A., Silva, R.J., Nguyen, S.N., Marquez, L.N. and Hudson, E.A. (1996) Determinations of uranium structures by EXAFS: Schoepite and other U(VI) oxide precipitates. Radiochim. Acta 75, 47-53.

Ankudinov, A.L., Ravel, B., Rehr, J.J. and Conradson, S.D. (1998) Real-space multiplescattering calculation and interpretation of $\mathrm{x}$-ray-absorption near-edge structure. Phys. Rev. B 58, 7565.

Bai, J., Liu, C.X. and Ball, W.P. (2009) Study of Sorption-Retarded U(VI) Diffusion in Hanford Silt/Clay Material. Environ. Sci. Technol. 43, 7706-7711.

Barnett, M.O., Jardine, P.M. and Brooks, S.C. (2002) U(VI) adsorption to heterogeneous subsurface media: Application of a surface complexation model. Environ. Sci. Technol. $36,937-942$.

Beazley, M.J., Martinez, R.J., Sobecky, P.A., Webb, S.M. and Taillefert, M. (2007) Uranium biomineralization as a result of bacterial phosphatase activity: Insights from bacterial isolates from a contaminated subsurface. Environ. Sci. Technol. 41, 5701-5707. 
Beazley, M.J., Martinez, R.J., Sobecky, P.A., Webb, S.M. and Taillefert, M. (2009) Nonreductive Biomineralization of Uranium(VI) Phosphate Via Microbial Phosphatase Activity in Anaerobic Conditions. Geomicrobiol. J. 26, 431-441.

Beazley, M.J., Martinez, R.J., Webb, S.M., Sobecky, P.A. and Taillefert, M. (2011) The effect of $\mathrm{pH}$ and natural microbial phosphatase activity on the speciation of uranium in subsurface soils. Geochim. Cosmochim. Acta 75, 5648-5663.

Belli, K., Taillefert, M., 2016. Biogeochemical processes regulating the mobility of uranium in sediments, in: Rinklebe, J., Knox, A.S., Paller, M. (Eds.), Trace elements in waterlogged soils and sediments. CRC Press, a Taylor \& Francis Company, pp. 185-223.

Bernier-Latmani, R., Veeramani, H., Vecchia, E.D., Junier, P., Lezama-Pacheco, J.S., Suvorova, E.I., Sharp, J.O., Wigginton, N.S. and Bargar, J.R. (2010) Non-uraninite Products of Microbial U(VI) Reduction. Environ. Sci. Technol. 44, 9456-9462.

Boyanov, M.I., Fletcher, K.E., Kwon, M.J., Rui, X., O'Loughlin, E.J., Loeffler, F.E. and Kemner, K.M. (2011) Solution and Microbial Controls on the Formation of Reduced U(IV) Species. Environ. Sci. Technol. 45, 8336-8344.

Brooks, S.C. (2001) Waste Characteristics of the Former S-3 Ponds and Outline of Uranium Chemistry Relevant to NABIR Field Research Center Studies. NABIR FRC.

Brooks, S.C., Fredrickson, J.K., Carroll, S.L., Kennedy, D.W., Zachara, J.M., Plymale, A.E., Kelly, S.D., Kemner, K.M. and Fendorf, S. (2003) Inhihition of bacterial U(VI) reduction by calcium. Environ. Sci. Technol. 37, 1850-1858.

Cigala, R.M., Crea, F., De Stefano, C., Lando, G., Milea, D., Sammartano, S., 2010. Electrochemical study on the stability of phytate complexes with $\mathrm{Cu}^{2+}, \mathrm{Pb}^{2+}, \mathrm{Zn}^{2+}$, and $\mathrm{Ni}^{2+}$ : A comparison of different techniques. J. Chem. Eng. Data 55, 4757-4767. 
644 Costello, A.J.R., Glonek, T. and Myers, T.C. (1976) P-31 Nuclear magnetic resonance - pH 645 titrations of myoinositol hexaphosphate. Carbohydr. Res. 46, 159-171.

646 Crea, F., De Stefano, C., Milea, D., Sammartano, S., 2008. Formation and stability of phytate 647 complexes in solution. Coord. Chem. Rev. 252, 1108-1120.

648

Degroot, C.J. and Golterman, H.L. (1993) On the presence of organic phosphate in some 649 camargue sediments-evidence for the importance of phytate. Hydrobiol. 252, 117-126.

650

DOE (1997) Linking Legacies - Connecting the Cold War Nuclear Weapons Production Processes to Their Environmental Consequences Office of Environmental Management The U.S. Department of Energy Washington, D.C.

653 654 655 656 657 658 659 660 661 662 663 664 665 666
Finch, R. and Murakami, T. (1999) Systematics and paragenesis of uranium minerals. Rev. Mineral. Geochem. 38, 91-179.

Finneran, K.T., Housewright, M.E. and Lovley, D.R. (2002) Multiple influences of nitrate on uranium solubility during bioremediation of uranium-contaminated subsurface sediments. Environ. Microbiol. 4, 510-516.

Fletcher, K.E., Boyanov, M.I., Thomas, S.H., Wu, Q.Z., Kemner, K.M. and Loffler, F.E. (2010) U(VI) Reduction to Mononuclear U(IV) by Desulfitobacterium Species. Environ. Sci. Technol. 44, 4705-4709.

Fredrickson, J.K., Zachara, J.M., Kennedy, D.W., Liu, C.X., Duff, M.C., Hunter, D.B. and Dohnalkova, A. (2002) Influence of Mn oxides on the reduction of uranium(VI) by the metal-reducing bacterium Shewanella putrefaciens. Geochim. Cosmochim. Acta 66, 3247-3262.

Grabias, E., Gladysz-Plaska, A., Ksiazek, A. and Majdan, M. (2014) Efficient uranium immobilization on red clay with phosphates. Environ. Chem. Lett. 12, 297-301. 
Gu, B.H., Wu, W.M., Ginder-Vogel, M.A., Yan, H., Fields, M.W., Zhou, J., Fendorf, S., Criddle, C.S. and Jardine, P.M. (2005) Bioreduction of uranium in a contaminated soil column. Environ. Sci. Technol. 39, 4841-4847.

Ha, N.C., Oh, B.C., Shin, S., Kim, H.J., Oh, T.K., Kim, Y.O., Choi, K.Y. and Oh, B.H. (2000) Crystal structures of a novel, thermostable phytase in partially and fully calcium-loaded states. Nature Struct. Biol. 7, 147-153.

Han, R.P., Zou, W.H., Wang, Y. and Zhu, L. (2007) Removal of uranium(VI) from aqueous solutions by manganese oxide coated zeolite: discussion of adsorption isotherms and $\mathrm{pH}$ effect. J. Environ. Radioact. 93, 127-143.

Hsi, C.K.D. and Langmuir, D. (1985) Adsorption of uranyl onto ferric oxyhydroxides Application of the surface complexation site-binding model. Geochim. Cosmochim. Acta 49, 1931-1941.

Hu, P., Brodie, E.L., Suzuki, Y., McAdams, H.H. and Andersen, G.L. (2005) Whole-genome transcriptional analysis of heavy metal stresses in Caulobacter crescentus. J. Bacteriol. $187,8437-8449$.

Hua, B. and Deng, B. (2008) Reductive Immobilization of Uranium(VI) by Amorphous Iron Sulfide. Environ. Sci. Technol. 42, 8703-8708.

Hudson, E.A., Allen, P.G., Terminello, L.J., Denecke, M.A. and Reich, T. (1996) Polarized xray-absorption spectroscopy of the uranyl ion: Comparison of experiment and theory. Phys. Rev. B 54, 156.

Irving, G.C. and Cosgrove, D.J. (1974) Inositol phosphate phosphatases of microbiological origin: Some properties of the partially purified phosphatases of Aspergillus ficuum NRRL 3135. Austr. J. Biol. Sci. 27, 361-368. 
Istok, J.D., Senko, J.M., Krumholz, L.R., Watson, D., Bogle, M.A., Peacock, A., Chang, Y.J. and White, D.C. (2004) In situ bioreduction of technetium and uranium in a nitratecontaminated aquifer. Environ. Sci. Technol. 38, 468-475.

Johnson, B.B., Quill, E. and Angove, M.J. (2012) An investigation of the mode of sorption of inositol hexaphosphate to goethite. J. Coll. Interf. Sci. 367, 436-442.

Jorquera, M., Martinez, O., Maruyama, F., Marschner, P. and de la Luz Mora, M. (2008) Current and future biotechnological applications of bacterial phytases and phytase-producing bacteria. Microbes and environments / JSME 23, 182-191.

Katsoyiannis, I.A. (2007) Carbonate effects and $\mathrm{pH}$-dependence of uranium sorption onto bacteriogenic iron oxides: Kinetic and equilibrium studies. J. Hazard. Mat. 139, 31-37.

Kelly, S.D., Kemner, K.M., Carley, J., Criddle, C., Jardine, P.M., Marsh, T.L., Phillips, D., Watson, D. and Wu, W.M. (2008) Speciation of uranium in sediments before and after in situ biostimulation. Environ. Sci. Technol. 42, 1558-1564.

Knox, A.S., Brimon, R.L., Kaplan, D.I. and Paller, M.H. (2008) Interactions among phosphate amendments, microbes and uranium mobility in contaminated sediments. Sci. Total Environ. 395, 63-71.

Langmuir, D. (1978) Uranium solution-mineral equilibria at low-temperatures with applications to sedimentary ore-deposits. Geochim. Cosmochim. Acta 42, 547-569.

Langmuir, D. (1997) Aqueous Environmental Geochemistry. Prentice Hall, Upper Saddle River, New Jersey.

Li, D., Seaman, J.C., Chang, H.S., Jaffe, P.R., van Groos, P.K., Jiang, D.T., Chen, N., Lin, J.R., Arthur, Z., Pan, Y.M., Scheckel, K.G., Newville, M., Lanzirotti, A. and Kaplan, D.I. 
(2014) Retention and chemical speciation of uranium in an oxidized wetland sediment from the Savannah River Site. J. Environ. Radioact. 131, 40-46.

Liger, E., Charlet, L. and Van Cappellen, P. (1999) Surface catalysis of uranium(VI) reduction by iron(II). Geochim. Cosmochim. Acta 63, 2939-2955.

Lim, B.L., Yeung, P., Cheng, C. and Hill, J.E. (2007) Distribution and diversity of phytatemineralizing bacteria. ISME 1, 321-330.

Liu, S.T., Musuku, S.R., Adhikari, S. and Fernando, S. (2009) Adsorption of glycerol from biodiesel washwaters. Environ. Technol. 30, 505-510.

Lovley, D.R., Phillips, E.J.P., Gorby, Y.A. and Landa, E.R. (1991) Microbial reduction of uranium Nature 350, 413-416.

Luo, W., Wu, W.-M., Yan, T., Criddle, C., Jardine, P., Zhou, J. and Gu, B. (2007) Influence of bicarbonate, sulfate, and electron donors on biological reduction of uranium and microbial community composition. App. Microbiol. Biotechnol. 77, 713-721.

Macaskie, L.E., Bonthrone, K.M. and Rouch, D.A. (1994) Phosphatase-mediated heavy metal accumulation by a Citrobacter sp. and related enterobacteria. FEMS Microbiol. Lett. 121, $141-146$.

Macaskie, L.E., Hewitt, C.J., Shearer, J.A. and Kent, C.A. (1995) Biomass production for the removal of heavy-metals from aqueous-solutions at low $\mathrm{pH}$ using growth-decoupled cells of a citrobacter sp. Inter. Biodeter. Biodegrad. 35, 73-92.

Martin, C.J. and Evans, W.J. (1987) Phytic acid-divalent cation interactions. V. Titrimetric, calorimetric, and binding-studies with Cobalt(II) and Nickel(II) and their comparison with ohter metal-ions J. Inorg. Biochem. 30, 101-119. 
Martinez, R.J., Beazley, M.J., Taillefert, M., Arakaki, A.K., Skolnick, J. and Sobecky, P.A. (2007) Aerobic uranium (VI) bioprecipitation by metal-resistant bacteria isolated from radionuclide- and metal-contaminated subsurface soils. Environ. Microbiol. 9, 31223133.

Meleshyn, A., Azeroual, M., Reeck, T., Houben, G., Riebe, B. and Bunnenberg, C. (2009) Influence of (Calcium-)Uranyl-Carbonate Complexation on U(VI) Sorption on Ca- and Na-Bentonites. Environ. Sci. Technol. 43, 4896-4901.

Missana, T., García-Gutiérrez, M. and Maffiotte, C. (2003) Experimental and modeling study of the uranium (VI) sorption on goethite. J Coll. Interf. Sci. 260, 291-301.

Montgomery, D.M., Dean, A.C.R., Wiffen, P. and Macaskie, L.E. (1995) Phosphatase production and activity in citrobacter-freundii and a naturally-occurring, heavy-metalaccumulating citrobacter sp. Microbiol. 141, 2433-2441.

Mukhametzyanova, A., Akhmetova, A. and Sharipova, M. (2012) Microorganisms as phytase producers. Microbiol. 81, 267-275.

Murphy, W.M. and Shock, E.L. (1999) Environmental aqueous geochemistry of actinides, in: Burns, P.C.a.F., R. (Ed.), Uranium: Mineralogy, Geochemistry and the Environment. Mineralogical Society of America, Washington, D.C., pp. 221-254.

Nash, K.L., Jensen, M.P. and Schmidt, M.A. (1998) Actinide immobilization in the subsurface environment by in-situ treatment with a hydrolytically unstable organophosphorus complexant: Uranyl uptake by calcium phytate. J. All. Comp. 271, 257-261.

North, N.N., Dollhopf, S.L., Petrie, L., Istok, J.D., Balkwill, D.L. and Kostka, J.E. (2004) Change in bacterial community structure during in situ Biostimulation of subsurface 
sediment cocontaminated with uranium and nitrate. App. Environ. Microbiol. 70, 49114920.

O'Loughlin, E.J., Kelly, S.D., Cook, R.E., Csencsits, R. and Kemner, K.M. (2003) Reduction of Uranium(VI) by mixed iron(II/iron(III) hydroxide (green rust): Formation of UO2 nanoparticies. Environ. Sci. Technol. 37, 721-727.

Oh, B.C., Choi, W.C., Park, S., Kim, Y.O. and Oh, T.K. (2004) Biochemical properties and substrate specificities of alkaline and histidine acid phytases. App. Microbiol. Biotechnol. $63,362-372$.

Paterson-Beedle, M., Readman, J.E., Hriljac, J.A. and Macaskie, L.E. (2010) Biorecovery of uranium from aqueous solutions at the expense of phytic acid. Hydrometal. 104, 524-528.

Plathe, K.L., Lee, S.W., Tebo, B.M., Bargar, J.R. and Bernier-Latmani, R. (2013) Impact of Microbial Mn Oxidation on the Remobilization of Bioreduced U(IV). Environ. Sci. Technol. 47, 3606-3613.

Powers, L.G., Mills, H.J., Palumbo, A.V., Zhang, C.L., Delaney, K. and Sobecky, P.A. (2002) Introduction of a plasmid-encoded phoA gene for constitutive overproduction of alkaline phosphatase in three subsurface Pseudomonas isolates. FEMS Microbiol. Ecol. 41, 115123.

Rao, D., Rao, K.V., Reddy, T.P. and Reddy, V.D. (2009) Molecular characterization, physicochemical properties, known and potential applications of phytases: An overview. Crit. Rev. Biotechnol. 29, 182-198.

Rounds, M.A. and Nielsen, S.S. (1993) Anion-exchange high-performance liquid chromatography with post-column detection for the analysis of phytic acid and other inositol phosphates. J. Chromatogr. A 653, 148-152. 
Salome, K.R., Green, S.J., Beazley, M.J., Webb, S.M., Kostka, J.E. and Taillefert, M. (2013) The role of anaerobic respiration in the immobilization of uranium through biomineralization of phosphate minerals. Geochim. Cosmochim. Acta 106, 344-363.

Sanford, R.A., Wu, Q., Sung, Y., Thomas, S.H., Amos, B.K., Prince, E.K. and Loffler, F.E. (2007) Hexavalent uranium supports growth of Anaeromyxobacter dehalogenans and Geobacter spp. with lower than predicted biomass yields. Environ. Microbiol. 9, 28852893.

Schecher, W.D. and McAvoy, D.C. (2001) MINEQL+: A Chemical Equilibrium Modeling System, Version 4.5 for Windows, User's Manual. Research Software, Hallowell, Maine.

Seaman, J.C., Hutchison, J.M., Jackson, B.P. and Vulava, V.M. (2003) In situ treatment of metals in contaminated soils with phytate. J. Environ. Qual. 32, 153-161.

Senko, J.M., Istok, J.D., Suflita, J.M. and Krumholz, L.R. (2002) In-situ evidence for uranium immobilization and remobilization. Environ. Sci. Technol. 36, 1491-1496.

Senko, J.M., Mohamed, Y., Dewers, T.A. and Krumholz, L.R. (2005a) Role for Fe(III) minerals in nitrate-dependent microbial U(IV) oxidation. Environ. Sci. Technol. 39, 2529-2536.

Senko, J.M., Suflita, J.M. and Krumholz, L.R. (2005b) Geochemical controls on microbial nitrate-dependent U(IV) oxidation. Geomicrobiol. J. 22, 371-378.

Sharp, J.O., Lezama-Pacheco, J.S., Schofield, E.J., Junier, P., Ulrich, K.-U., Chinni, S., Veeramani, H., Margot-Roquier, C., Webb, S.M., Tebo, B.M., Giammar, D.E., Bargar, J.R. and Bernier-Latmani, R. (2011) Uranium speciation and stability after reductive immobilization in aquifer sediments. Geochim. Cosmochim. Acta 75, 6497-6510. 
Shelobolina, E.S., Konishi, H., Xu, H.F. and Roden, E.E. (2009) U(VI) Sequestration in Hydroxyapatite Produced by Microbial Glycerol 3-Phosphate Metabolism. App. Environ. Microbiol. 75, 5773-5778.

Sitte, J., Akob, D.M., Kaufmann, C., Finster, K., Banerjee, D., Burkhardt, E.M., Kostka, J.E., Scheinost, A.C., Buchel, G. and Kuesel, K. (2010) Microbial Links between Sulfate Reduction and Metal Retention in Uranium- and Heavy Metal-Contaminated Soil. App. Environ. Microbiol. 76, 3143-3152.

Sobecky, P.A., Schell, M.A., Moran, M.A. and Hodson, R.E. (1996) Impact of a genetically engineered bacterium with enhanced alkaline phosphatase activity on marine phytoplankton communities. App. Environ. Microbiol. 62, 6-12.

Stubbs, J.E., Elbert, D.C., Veblen, D.R. and Zhu, C. (2006) Electron microbeam investigation of uranium-contaminated soils from Oak Ridge, TN, USA. Environ. Sci. Technol. 40, 21082113.

Tebo, B.M. and Obraztsova, A.Y. (1998) Sulfate-reducing bacterium grows with Cr(VI), U(VI), Mn(IV), and Fe(III) as electron acceptors. FEMS Microbiology Letters 162, 193-198.

Tessier, A., Campbell, P.G.C. and Bisson, M. (1979) Sequential extraction procedure for the speciation of particulate trace-metals. Anal. Chem. 51, 844-851.

Turner, B.L. (2007) Inositol phosphates in soil: Amounts, forms and significance of the phosphorylated inositol stereoisomers in: Turner, B.L., Richardson, A.E., Mullaney, E.J. (Eds.), Inositol Phosphates: Linking Agriculture and the Environment. CABI, Wallingford, UK, pp. 186-208.

Turner, B.L., Paphazy, M.J., Haygarth, P.M. and McKelvie, I.D. (2002) Inositol phosphates in the environment. Phil. Trans. Roy. Soc. Lon. B 357, 449-469. 
Van Nostrand, J.D., Wu, L., Wu, W.-M., Huang, Z., Gentry, T.J., Deng, Y., Carley, J., Carroll, S., He, Z., Gu, B., Luo, J., Criddle, C.S., Watson, D.B., Jardine, P.M., Marsh, T.L., Tiedje, J.M., Hazen, T.C. and Zhou, J. (2011) Dynamics of Microbial Community Composition and Function during In Situ Bioremediation of a Uranium-Contaminated Aquifer. App. Environ. Microbiol. 77, 3860-3869.

Violante, A. and Pigna, M. (2002) Competitive sorption of arsenate and phosphate on different clay minerals and soils. Soil Sci. Soc. Am. J. 66, 1788-1796.

Wade, R. and DiChristina, T.J. (2000) Isolation of U(VI) reduction-deficient mutants of Shewanella putrefaciens. FEMS Microbiol. Lett. 184, 143-148.

Waite, T.D., Davis, J.A., Payne, T.E., Waychunas, G.A. and Xu, N. (1994) Uranium(VI) adsorption to ferrihydrite- application of a surface complexation model. Geochim. Cosmochim. Acta 58, 5465-5478.

Wan, J.M., Tokunaga, T.K., Brodie, E., Wang, Z.M., Zheng, Z.P., Herman, D., Hazen, T.C., Firestone, M.K. and Sutton, S.R. (2005) Reoxidation of bioreduced uranium under reducing conditions. Environ. Sci. Technol. 39, 6162-6169.

Webb, S.M. (2005) SIXpack: a graphical user interface for XAS analysis using IFEFFIT. Phys. Script. T115, 1011-1014.

Webb, S.M., Fuller, C.C., Tebo, B.M. and Bargar, J.R. (2006) Determination of uranyl incorporation into biogenic manganese oxides using X-ray absorption spectroscopy and scattering. Environ. Sci. Technol. 40, 771-777.

Wellman, D.M., Icenhower, J.P. and Owen, A.T. (2006) Comparative analysis of soluble phosphate amendments for the remediation of heavy metal contaminants: Effect on sediment hydraulic conductivity. Environ. Chem. 3, 219-224. 
Wersin, P., Hochella, M.F., Persson, P., Redden, G., Leckie, J.O. and Harris, D.W. (1994) Interaction between aqueous uranium(VI) and sulfide minerals - spectroscopic evidence for sorption and reduction. Geochim. Cosmochim. Acta 58, 2829-2843.

Wu, W.M., Carley, J., Fienen, M., Mehlhorn, T., Lowe, K., Nyman, J., Luo, J., Gentile, M.E., Rajan, R., Wagner, D., Hickey, R.F., Gu, B.H., Watson, D., Cirpka, O.A., Kitanidis, P.K., Jardine, P.M. and Criddle, C.S. (2006a) Pilot-scale in situ bioremediation of uranium in a highly contaminated aquifer. 1. Conditioning of a treatment zone. Environ. Sci. Technol. 40, 3978-3985.

Wu, W.M., Carley, J., Gentry, T., Ginder-Vogel, M.A., Fienen, M., Mehlhorn, T., Yan, H., Caroll, S., Pace, M.N., Nyman, J., Luo, J., Gentile, M.E., Fields, M.W., Hickey, R.F., Gu, B.H., Watson, D., Cirpka, O.A., Zhou, J.Z., Fendorf, S., Kitanidis, P.K., Jardine, P.M. and Criddle, C.S. (2006b) Pilot-scale in situ bioremedation of uranium in a highly contaminated aquifer. 2. Reduction of $\mathrm{U}(\mathrm{VI})$ and geochemical control of $\mathrm{U}(\mathrm{VI})$ bioavailability. Environ. Sci. Technol. 40, 3986-3995.

Wu, W.M., Carley, J., Luo, J., Ginder-Vogel, M.A., Cardenas, E., Leigh, M.B., Hwang, C.C., Kelly, S.D., Ruan, C.M., Wu, L.Y., Van Nostrand, J., Gentry, T., Lowe, K., Mehlhorn, T., Carroll, S., Luo, W.S., Fields, M.W., Gu, B.H., Watson, D., Kemner, K.M., Marsh, T., Tiedje, J., Zhou, J.Z., Fendorf, S., Kitanidis, P.K., Jardine, P.M. and Criddle, C.S. (2007) In situ bioreduction of uranium (VI) to submicromolar levels and reoxidation by dissolved oxygen. Environ. Sci. Technol. 41, 5716-5723.

Yong, P. and Macaskie, L.E. (1995) Enhancement of uraium bioaccumulation by a Citrobacter sp. via enzymatically-mediated growth of polycrystalline NH4UO2PO4. J. Chem. Technol. Biotechnol. 63, 101-108. 
869 Yung, M.M.C., Ma, J.C., Salemi, M.R., Phinney, B.S., Bowman, G.R. and Jiao, Y.Q. (2014)

870 Shotgun Proteomic Analysis Unveils Survival and Detoxification Strategies by

871 Caulobacter crescentus during Exposure to Uranium, Chromium, and Cadmium. J.

$872 \quad$ Proteome Res. 13, 1833-1847.

873 Zabinsky, S.I., Rehr, J.J., Ankudinov, A., Albers, R.C. and Eller, M.J. (1995) Multiple-scattering 874 calculations of X-ray absorption spectra. Phys. Rev. B 52, 2995-3009. 
Table 1. Orthophosphate liberation rate and Inositol Hexaphosphate ( $\mathrm{IP}_{6}$, Phytate) consumption 885 rate in $\mathrm{pH} 5.5$ reactors amended with $10 \mathrm{mM}$ Phytate $(+\mathrm{P}-\mathrm{G}-\mathrm{U}) ; 10 \mathrm{mM}$ Phytate and $200 \mu \mathrm{M}$ $886 \mathrm{U}(\mathrm{VI})(+\mathrm{P}-\mathrm{G}+\mathrm{U}) ; 10 \mathrm{mM}$ Phytate and $10 \mathrm{mM}$ glycerol $(+\mathrm{P}+\mathrm{G}-\mathrm{U})$; or $10 \mathrm{mM}$ Phytate, 10 887 $\mathrm{mM}$ Glycerol, and $200 \mu \mathrm{M} \mathrm{U}(\mathrm{VI})(+\mathrm{P}+\mathrm{G}+\mathrm{U})$.

Treatment $d\left(\sum \mathrm{PO}_{4}^{3-}\right) / d t$ $d\left(I P_{6}\right) / d t$

\begin{tabular}{lcc}
\hline \hline$+\mathrm{P}-\mathrm{G}-\mathrm{U}$ & $13.5 \pm 2.6 \mathrm{mMd}^{-1}$ & $0.92 \pm 0.22 \mathrm{mMd}^{-1}$ \\
$+\mathrm{P}+\mathrm{G}-\mathrm{U}$ & $20.5 \pm 5.1 \mathrm{mMd}^{-1}$ & $2.5 \pm 0.58 \mathrm{mMd}^{-1}$ \\
$+\mathrm{P}-\mathrm{G}+\mathrm{U}$ & $4.6 \pm 0.3 \mathrm{mMd}^{-1}$ & $1.7 \pm 0.38 \mathrm{mMd}^{-1}$ \\
$+\mathrm{P}+\mathrm{G}+\mathrm{U}$ & $5.6 \pm 0.4 \mathrm{mMd}^{-1}$ & $2.9 \pm 0.21 \mathrm{mMd}^{-1}$ \\
\hline
\end{tabular}

888

889

890

891

892

893

894

895

896

897 
Table 2. Fitting Parameters for $\mathrm{U}_{\mathrm{III}}$-edge EXAFS derived using SIXPACK (Webb, 2005) in soil slurries treated with a (pH 5.5, $200 \mu \mathrm{M} \mathrm{U}), \mathrm{b}\left(\mathrm{pH} 5.5,200 \mu \mathrm{M} \mathrm{U}+10 \mathrm{mM} \mathrm{IP}_{6}\right), \mathrm{c}(\mathrm{pH} 5.5$, $200 \mu \mathrm{M} \mathrm{U}+10 \mathrm{mM} \mathrm{IP}_{6}+10 \mathrm{mM}$ glycerol), d (pH 7.0, $200 \mu \mathrm{M} \mathrm{U}+10 \mathrm{mM}$ DIC), e (pH 7.0, $200 \mu \mathrm{M} \mathrm{U}+10 \mathrm{mM}$ DIC $\left.+10 \mathrm{mM} \mathrm{IP}_{6}\right)$, and $\mathrm{f}\left(\mathrm{pH} 7.0,200 \mu \mathrm{M} \mathrm{U}+10 \mathrm{mM} \mathrm{IP}_{6}+10 \mathrm{mM}\right.$ glycerol + $10 \mathrm{mM}$ DIC). $\mathrm{N}$ represents $\mathrm{U}$-ligand coordination number, $\mathrm{R}(\AA)$ represents $\mathrm{U}$-ligand distance.

\begin{tabular}{|c|c|c|c|c|c|c|}
\hline Treatment & Shell & $N$ & $R(\AA)$ & $\sigma^{2}\left(\AA^{2}\right)$ & $\Delta E_{0}(e V)$ & $R$ factor \\
\hline \multirow[t]{4}{*}{$\overline{\mathrm{A}}$} & $\overline{\mathrm{O}_{\mathrm{ax}}}$ & 2.0 & $1.78(0.01)$ & $0.005(0.001)$ & $6.21(3.90)$ & 0.0098 \\
\hline & $\mathrm{O}_{\mathrm{eq}}$ & $3.26(1.43)$ & $2.26(0.03)$ & 0.009 & & \\
\hline & $\mathrm{O}_{\mathrm{eq}}$ & $1.77(0.64)$ & $2.42(0.03)$ & 0.003 & & \\
\hline & $\mathrm{Mn} / \mathrm{Fe}$ & $0.77(0.39)$ & $3.38(0.06)$ & 0.003 & & \\
\hline \multirow[t]{4}{*}{ B } & $\mathrm{O}_{\mathrm{ax}}$ & 2.0 & $1.79(0.01)$ & $0.004(0.001)$ & $10.0(2.13)$ & 0.0159 \\
\hline & $\mathrm{O}_{\mathrm{eq}}$ & $4.04(0.95)$ & $2.34(0.02)$ & 0.009 & & \\
\hline & $\mathrm{Mn} / \mathrm{Fe}$ & $0.63(0.23)$ & $3.46(0.02)$ & 0.003 & & \\
\hline & $\mathrm{P}$ & $0.39(0.44)$ & $3.88(0.06)$ & 0.002 & & \\
\hline \multirow[t]{4}{*}{$\mathrm{C}$} & $\mathrm{O}_{\mathrm{ax}}$ & 2.0 & $1.78(0.01)$ & $0.004(0.001)$ & $8.72(2.29)$ & 0.0122 \\
\hline & $\mathrm{O}_{\mathrm{eq}}$ & $3.79(0.93)$ & $2.34(0.02)$ & 0.009 & & \\
\hline & $\mathrm{Mn} / \mathrm{Fe}$ & $0.58(0.22)$ & $3.45(0.02)$ & 0.003 & & \\
\hline & $\mathrm{P}$ & $0.55(0.45)$ & $3.89(0.05)$ & 0.002 & & \\
\hline \multirow[t]{5}{*}{ D } & $\mathrm{O}_{\mathrm{ax}}$ & 2.0 & $1.78(0.02)$ & $0.006(0.001)$ & $3.99(4.37)$ & 0.0085 \\
\hline & $\mathrm{O}_{\mathrm{eq}}$ & $3.28(1.23)$ & $2.25(0.04)$ & 0.009 & & \\
\hline & $\mathrm{O}_{\mathrm{eq}}$ & $1.20(0.46)$ & $2.41(0.04)$ & 0.003 & & \\
\hline & $\mathrm{C}$ & $0.60(0.24)$ & $2.90(0.03)$ & 0.009 & & \\
\hline & $\mathrm{Mn} / \mathrm{Fe}$ & $0.24(0.14)$ & $3.43(0.04)$ & 0.003 & & \\
\hline \multirow[t]{4}{*}{ E } & $\mathrm{O}_{\mathrm{ax}}$ & 2.0 & $1.77(0.02)$ & $0.003(0.002)$ & $4.70(3.51)$ & 0.0336 \\
\hline & $\mathrm{O}_{\mathrm{eq}}$ & $4.70(1.90)$ & $2.29(0.03)$ & 0.009 & & \\
\hline & $\mathrm{C}$ & $1.59(0.63)$ & $2.94(0.03)$ & 0.009 & & \\
\hline & $\mathrm{Mn} / \mathrm{Fe}$ & $0.31(0.35)$ & $3.49(0.06)$ & 0.003 & & \\
\hline \multirow[t]{4}{*}{$\mathrm{F}$} & $\mathrm{O}_{\mathrm{ax}}$ & 2.0 & $1.77(0.01)$ & $0.004(0.001)$ & $7.10(2.55)$ & 0.0145 \\
\hline & $\mathrm{O}_{\mathrm{eq}}$ & $4.91(1.32)$ & $2.29(0.02)$ & 0.009 & & \\
\hline & $\mathrm{C}$ & $0.74(0.32)$ & $2.92(0.03)$ & 0.009 & & \\
\hline & $\mathrm{Mn} / \mathrm{Fe}$ & $0.66(0.23)$ & $3.45(0.02)$ & 0.003 & & \\
\hline
\end{tabular}


Table 3. Predicted solution equilibrium and solid phase saturation indices using MINEQL+ (Schecher and McAvoy, 2001) in pH 5.5 and 7.0 soil slurries. Solution concentrations are reported in percent of total species. For solid phase species, values reported represent saturation indices for each mineral phase, and numbers in parentheses represent the percentage of uranium precipitated as each respective mineral. Each $\mathrm{pH} 7.0$ treatment was modeled as a closed system $(\mathrm{DIC}=10 \mathrm{mM})$ using the maximum measured inorganic phosphate concentration and initial conditions as input for all other species. A double layer sorption model onto amorphous Feoxide $\left(0.41 \mathrm{~g} / \mathrm{L}, 600 \mathrm{~m}^{2} / \mathrm{g}\right.$ surface area) was included in the calculations. Unless otherwise noted, $\log \mathrm{K}$ values are as reported in Schecher and McAvoy (2001).

\begin{tabular}{|c|c|c|c|c|c|}
\hline \multirow[b]{2}{*}{$U(V I)$ Species } & \multirow[b]{2}{*}{$\log K$} & \multicolumn{4}{|c|}{ Treatment } \\
\hline & & 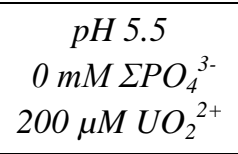 & 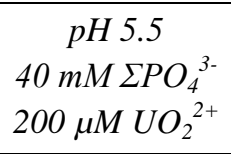 & 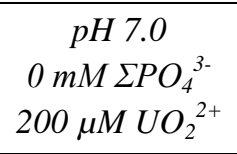 & 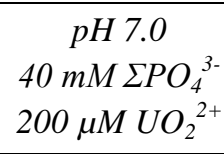 \\
\hline \multicolumn{6}{|l|}{ Aqueous } \\
\hline $\mathrm{UO}_{2}^{2+}$ & & $1.4 \%$ & $0.0 \%$ & $0.0 \%$ & $0.0 \%$ \\
\hline$\left(\mathrm{UO}_{2}\right)_{2} \mathrm{OH}_{2}{ }^{2+}$ & $-5.62^{a, b}$ & $1.2 \%$ & $0.0 \%$ & $0.0 \%$ & $0.0 \%$ \\
\hline $\mathrm{UO}_{2} \mathrm{OH}^{+}$ & $-5.20^{\mathrm{a}, \mathrm{b}}$ & $1.8 \%$ & $0.0 \%$ & $0.0 \%$ & $0.0 \%$ \\
\hline$\left(\mathrm{UO}_{2}\right)_{3}(\mathrm{OH})_{5}^{+}$ & $-15.55^{\mathrm{a}, \mathrm{b}}$ & $5.6 \%$ & $0.0 \%$ & $0.0 \%$ & $0.0 \%$ \\
\hline $\mathrm{UO}_{2} \mathrm{PO}_{4}^{-}$ & $13.23^{\mathrm{b}}$ & $0.0 \%$ & $0.0 \%$ & $0.0 \%$ & $0.0 \%$ \\
\hline $\mathrm{UO}_{2}\left(\mathrm{CO}_{3}\right)^{4-}$ & $21.84^{\mathrm{c}}$ & $0.0 \%$ & $0.0 \%$ & $30.5 \%$ & $0.0 \%$ \\
\hline $\mathrm{UO}_{2}\left(\mathrm{CO}_{3}\right)_{2}{ }^{2-}$ & $16.81^{\mathrm{c}}$ & $0.0 \%$ & $0.0 \%$ & $9.2 \%$ & $0.0 \%$ \\
\hline $\mathrm{CaUO}_{2}\left(\mathrm{CO}_{3}\right)_{3}{ }^{2-}$ & $27.18^{\mathrm{d}}$ & $0.0 \%$ & $0.0 \%$ & $46.8 \%$ & $0.0 \%$ \\
\hline $\mathrm{Ca} 2 \mathrm{UO}_{2}\left(\mathrm{CO}_{3}\right)_{3}$ & $30.7^{\mathrm{d}}$ & $0.0 \%$ & $0.0 \%$ & $3.7 \%$ & $0.0 \%$ \\
\hline $\mathrm{Fe}(\mathrm{wk}) \mathrm{OH}-\mathrm{UO}_{2}(\mathrm{OH})_{2}$ & $-6.28^{e}$ & $6.5 \%$ & $0.0 \%$ & $0.0 \%$ & $0.0 \%$ \\
\hline $\mathrm{Fe}(\mathrm{st}) \mathrm{OH}-\mathrm{UO}_{2}(\mathrm{OH})_{2}$ & $-2.57^{\mathrm{e}}$ & $11.4 \%$ & $0.0 \%$ & $9.2 \%$ & $0.0 \%$ \\
\hline \multicolumn{6}{|l|}{ Solid Phase } \\
\hline Schoepite & $-5.2^{\mathrm{a}}$ & $0(71.6 \% \mathrm{U})$ & -5.5 & -1.816 & -5.965 \\
\hline Na-Autunite & 47.4 & -28.5 & $0(100 \% \mathrm{U})$ & -29.1 & $0(100 \% \mathrm{U})$ \\
\hline Ca-Autunite & $27.2^{\mathrm{a}}$ & -30.8 & -2.5 & -31.5 & -3.503 \\
\hline
\end{tabular}




\section{FIGURE CAPTIONS}

898 Figure 1: A) Phytate $\left(\mathrm{IP}_{6}\right)$ speciation as a function of $\mathrm{pH}$ as calculated by MINEQL+ (Schecher and McAvoy, 2001) using $\mathrm{pK}_{\mathrm{a}}$ values reported in Costello et al. (1976). Total phytate concentrations set at $10 \mathrm{mM}$. Vertical dashed lines represent the experimental conditions of the present study. B) Uranium solubility in the presence of increasing concentrations of phytate at both pH 5.5 (close squares) and 7.0 (open circles) in artificial groundwater equilibrated for 1 week. Initial uranium concentration was $200 \mu \mathrm{M}$ in all experiments (horizontal dashed line), and error bars represent variation between triplicate experiments and analytical error on duplicate measurements. Labels $1,2,3,4,5,6,7$, and 8 represent $\left[\mathrm{IP}_{6}\right]:[\mathrm{U}]$ molar ratios of 1:4, 1:2, 1:1, $3: 1,5: 1,15: 1,25: 1$ and 50:1.

Figure 2: Evolution of inorganic phosphate $\left(\Sigma \mathrm{PO}_{4}{ }^{3-}\right)$ as a function of time in $\mathrm{pH} 5.5$ (symbols with solid lines) and pH 7.0 (symbols with dashed lines) sediment slurries containing $16 \mathrm{~g} / \mathrm{L}$ Area 3 Oak Ridge Field Research Center sediments and artificial groundwater amended with: A) $10 \mathrm{mM}$ phytate and $10 \mathrm{mM}$ glycerol $(+\mathrm{P}+\mathrm{G}-\mathrm{U}) ; 10 \mathrm{mM}$ phytate only $(+\mathrm{P}-\mathrm{G}-\mathrm{U})$; and $\mathrm{B}) 10$ $\mathrm{mM}$ phytate, $10 \mathrm{mM}$ glycerol, and $200 \mu \mathrm{M} \mathrm{UO}_{2}{ }^{2+}(+\mathrm{P}+\mathrm{G}+\mathrm{U}) ; 10 \mathrm{mM}$ phytate and $200 \mu \mathrm{M}$ $\mathrm{UO}_{2}{ }^{2+}(+\mathrm{P}-\mathrm{G}+\mathrm{U})$ and $200 \mu \mathrm{M} \mathrm{UO}_{2}{ }^{2+}$ only $(-\mathrm{P}-\mathrm{G}+\mathrm{U})$. All pH 7.0 reactors also received 10 $\mathrm{mM}$ dissolved inorganic carbon (DIC) to account for the potential effect of carbonates on uranyl 914 speciation at that $\mathrm{pH}$. Closed symbols represent slurries amended with glycerol and triangles 915 represent slurries without uranium. Error bars include variation between triplicate reactors and 916 the analytical error on duplicate measurements. The short-dashed box delineates the zoomed area 917 depicted in Figure 4B.

Figure 3: Evolution of inositol hexaphosphate $\left(\operatorname{IP}_{6}\right)$ and its lower derivatives $\left(\operatorname{IP}_{x}, x=2: 5\right)$ as a 919 function of time in $\mathrm{pH} 5.5$ (symbols with solid lines) and $\mathrm{pH} 7.0$ (symbols with dashed lines) 
920 slurries containing 16 g/L Area 3 Oak Ridge Field Research Center sediments in artificial 921 groundwater amended with: A) $10 \mathrm{mM}$ phytate (+ P - G - U); B) $10 \mathrm{mM}$ phytate and $10 \mathrm{mM}$ 922 glycerol $(+\mathrm{P}+\mathrm{G}-\mathrm{U})$; C) $10 \mathrm{mM}$ phytate, and $200 \mu \mathrm{M} \mathrm{UO}_{2}{ }^{2+}(+\mathrm{P}-\mathrm{G}+\mathrm{U})$; and D) $10 \mathrm{mM}$ 923 phytate, $10 \mathrm{mM}$ glycerol, and $200 \mu \mathrm{M} \mathrm{UO}_{2}{ }^{2+}(+\mathrm{P}+\mathrm{G}+\mathrm{U})$. Reactors buffered at $\mathrm{pH} 7.0$ were 924 also amended with $10 \mathrm{mM}$ dissolved inorganic carbon (DIC) to account for the potential effect of 925 carbonates on uranyl speciation at that $\mathrm{pH}$. Error bars include variation between triplicate 926 reactors and analytical error from calibrations.

927 Figure 4: A) Evolution of dissolved uranium as a function of time in pH 5.5 (symbols with solid 928 lines) and pH 7.0 (symbols with dashed lines) sedimennt slurries containing 16 g/L Area 3 Oak 929 Ridge Field Research Center sediments and artificial groundwater amended with 10 mM phytate, $93010 \mathrm{mM}$ glycerol, and $200 \mu \mathrm{M} \mathrm{UO}_{2}{ }^{2+}(+\mathrm{P}+\mathrm{G}+\mathrm{U}) ; 10 \mathrm{mM}$ phytate and $200 \mu \mathrm{M} \mathrm{UO}_{2}{ }^{2+}(+\mathrm{P}-\mathrm{G}$ $931+\mathrm{U})$; and $200 \mu \mathrm{M} \mathrm{UO}_{2}{ }^{2+}$ only $(-\mathrm{P}-\mathrm{G}+\mathrm{U})$. All $\mathrm{pH} 7.0$ reactors also received $10 \mathrm{mM}$ dissolved 932 inorganic carbon (DIC) to account for the potential effect of carbonates on uranyl speciation at 933 that $\mathrm{pH}$. The short-dashed box delineates the zoomed area depicted in Figure 4B. B) Close up 934 view of the evolution of inorganic phosphate $\left(\mathrm{POO}_{4}{ }^{3-}\right)$ (red) and dissolved uranium (black) 935 during the first week of incubation of $\mathrm{pH} 5.5$ soil slurries shown in Figures 2 and 4A; these 936 slurry incubations contained 16 g/L Area 3 Oak Ridge Field Research Center sediments and 937 artificial groundwater amended with $10 \mathrm{mM}$ phytate, $10 \mathrm{mM}$ glycerol, and $200 \mu \mathrm{M} \mathrm{UO}_{2}{ }^{2+}(+\mathrm{P}+$ $938 \mathrm{G}+\mathrm{U})$ or $10 \mathrm{mM}$ phytate and $200 \mu \mathrm{M} \mathrm{UO}_{2}{ }^{2+}(+\mathrm{P}-\mathrm{G}+\mathrm{U})$. Closed and open symbols represent 939 slurries with and without glycerol, respectively. Error bars represent variation between triplicate 940 reactors and include the analytical error on duplicate measurements.

941 Figure 5: Solid phase-associated $\mathrm{U}$ in: A) $\mathrm{pH} 5.5$; and B) $\mathrm{pH} 7.0$ sediments after 16 days of 942 incubation extracted using a modified sequential extraction technique of Tessier (1979). Bars 
943 represent the fraction of $U$ extracted during each individual extraction step relative to total 944 extracted uranium in each treatment. Symbols represent the percent uranium recovered in each 945 treatment. All error bars include the variation between triplicate reactors and duplicate 946 extractions.

947 Figure 6: Uranium: A) XANES; B) R-space; and C) k-space diagrams of the LIII-edge EXAFS 948 obtained from Area 3 sediments of the Oak Ridge Field Research Center following aerobic 949 incubation in sediment slurries for 16 days at $\mathrm{pH} 5.5$ and 7.0. Treatments included a: $\mathrm{pH}$ 5.5, 200 $950 \mu \mathrm{M} \mathrm{U} ; \mathrm{b}: \mathrm{pH} 5.5,200 \mu \mathrm{M} \mathrm{U}+10 \mathrm{mM} \mathrm{IP}$; c: pH 5.5, $200 \mu \mathrm{M} \mathrm{U}+10 \mathrm{mM} \mathrm{IP}_{6}+10 \mathrm{mM}$ 951 glycerol; d: pH 7.0, $200 \mu \mathrm{M} \mathrm{U}$; e: pH 7.0, $200 \mu \mathrm{M} \mathrm{U}+10$ mM IP 6 ; and f: pH 7.0, $200 \mu \mathrm{M} \mathrm{U}+10$ $952 \mathrm{mM} \mathrm{IP}_{6}+10 \mathrm{mM}$ glycerol. 

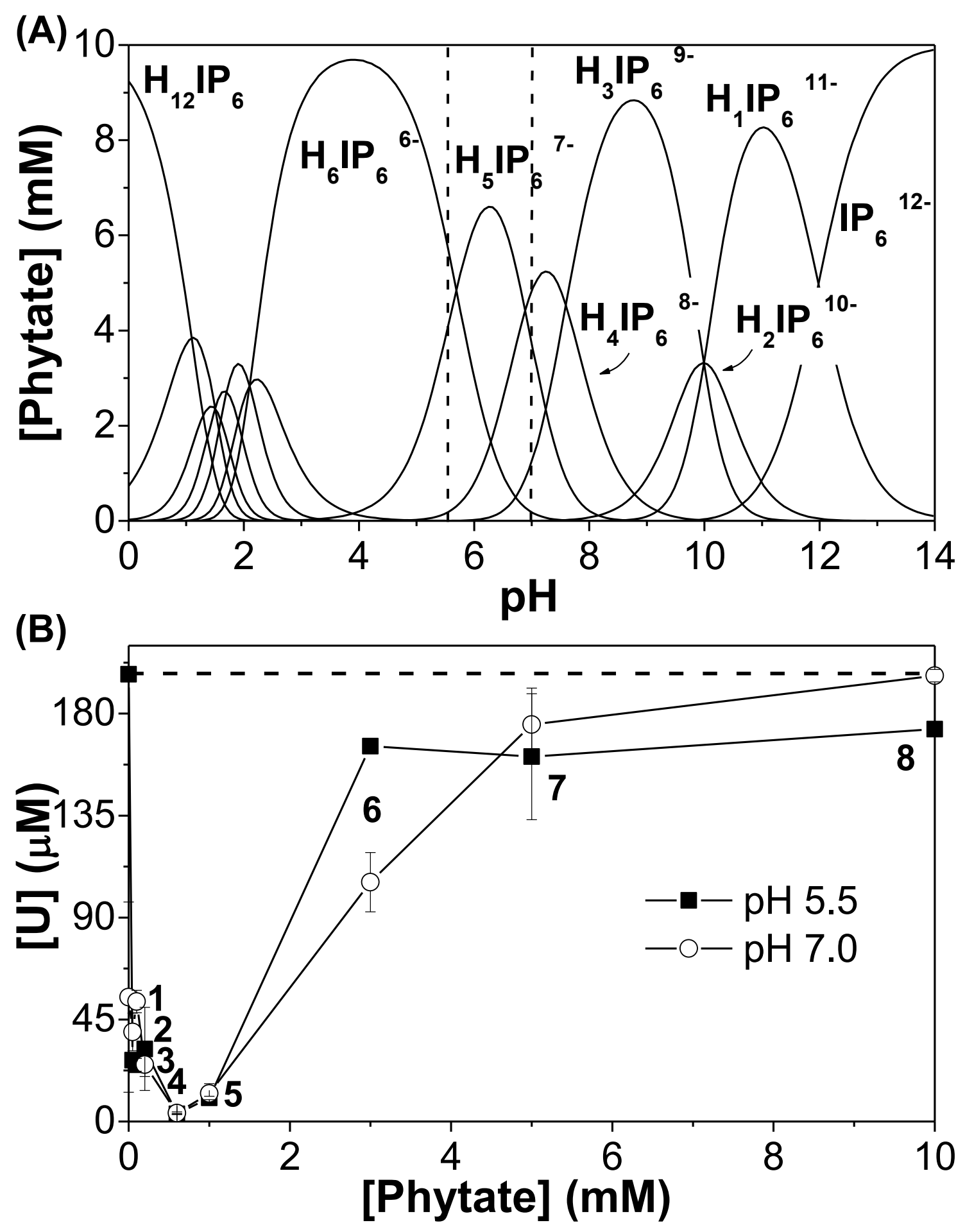

Figure 1.- Salome et al., 2015 
pH 5.5
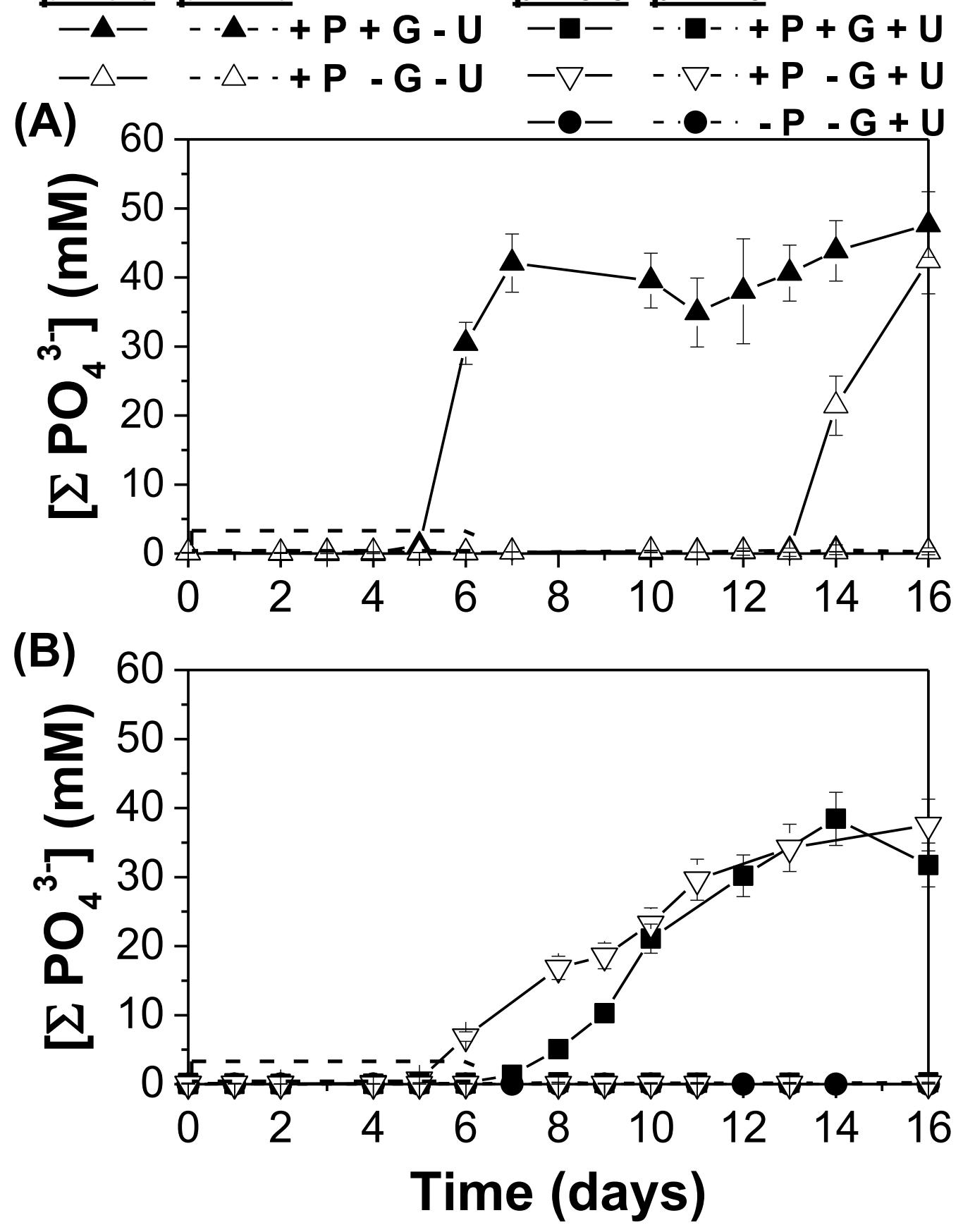

Figure 2.- Salome et al., 2015 


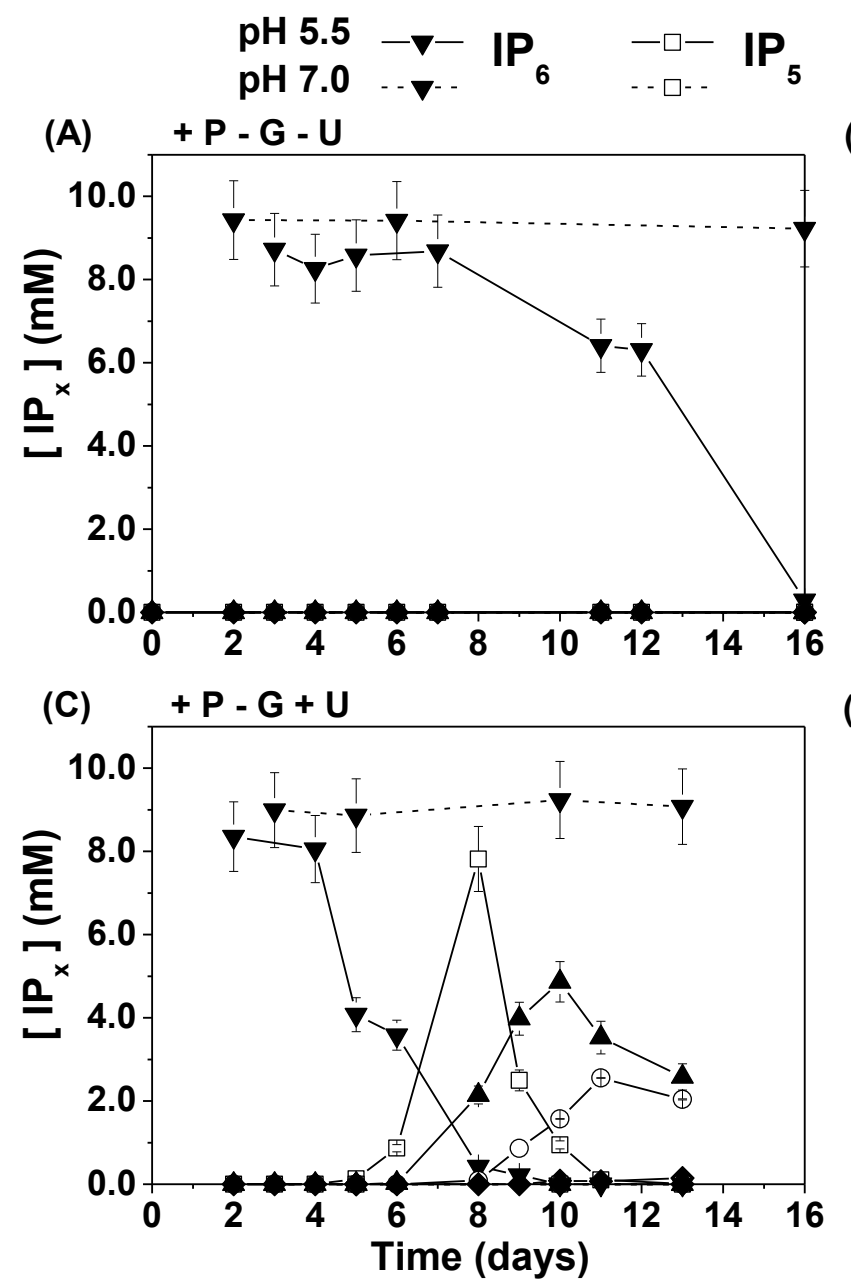

$\begin{array}{llllll}-\Delta- & I_{4} & -0- & I_{3} & \longrightarrow & I_{3}\end{array}$

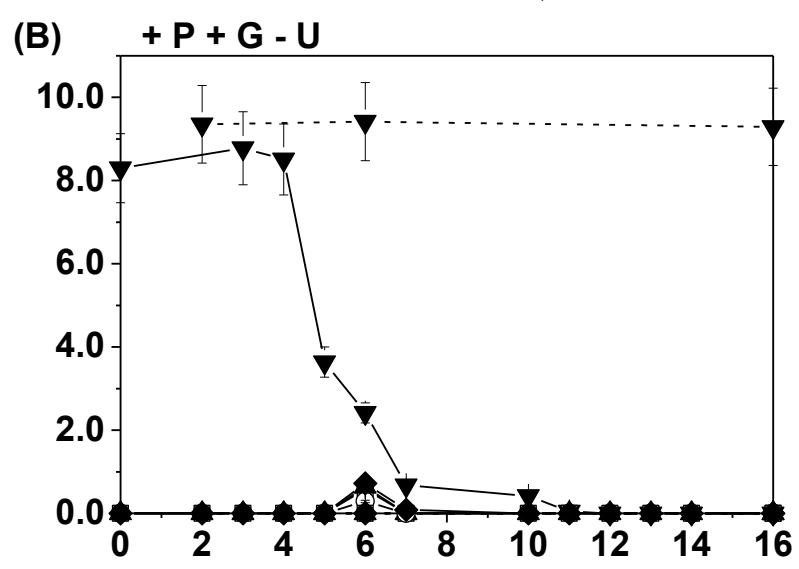

(D)

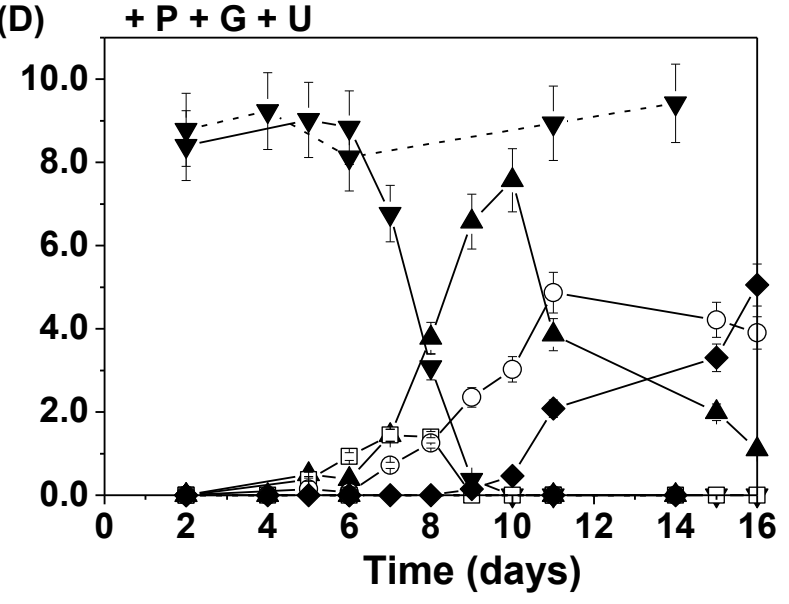

Figure 3.- Salome et al., 2015 
(A)

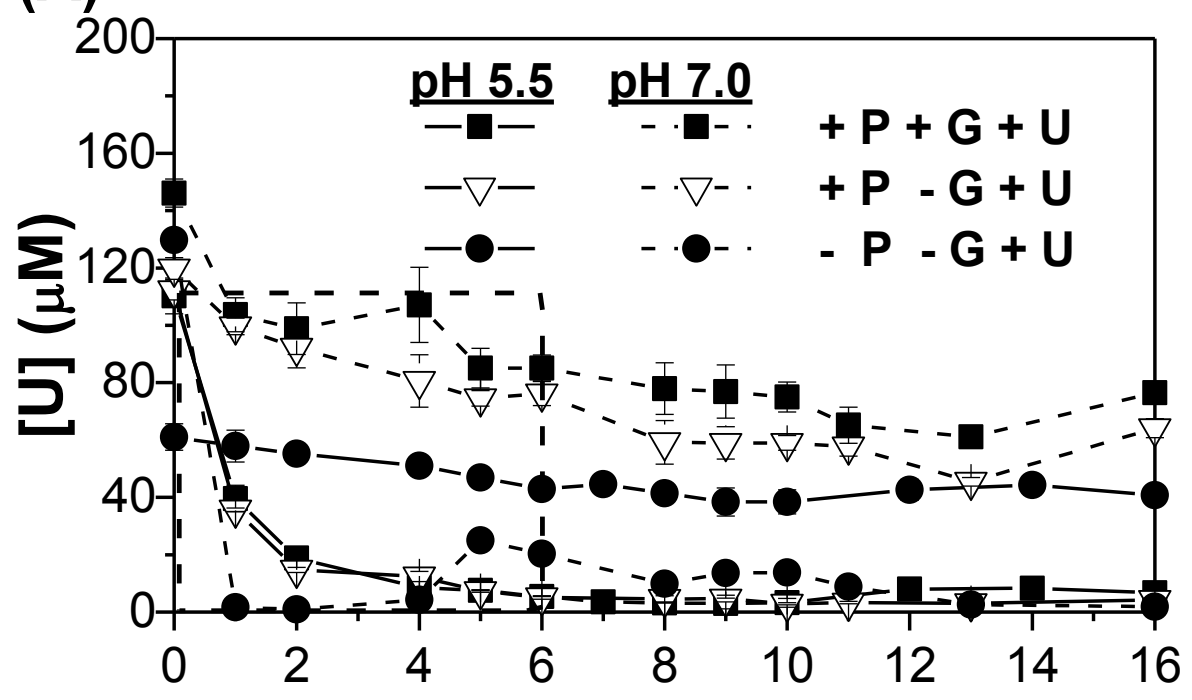

(B)

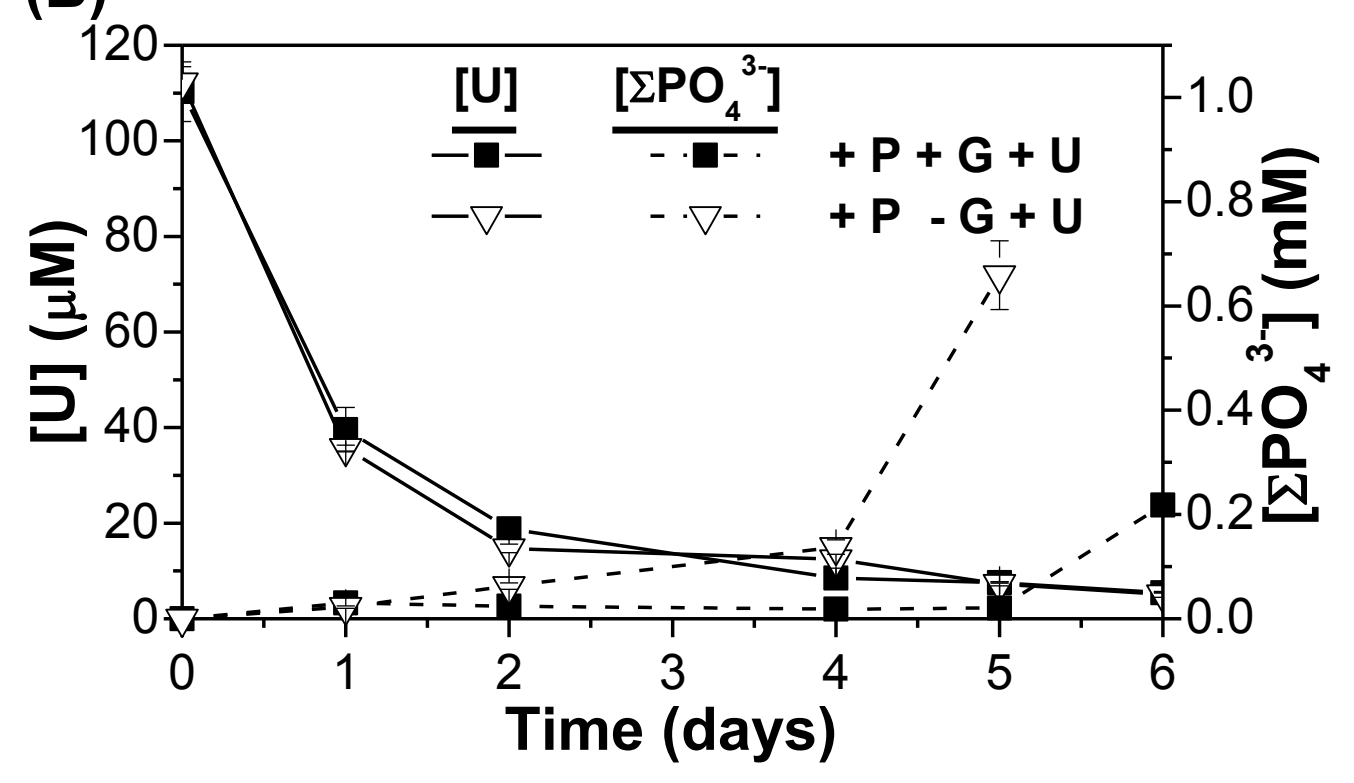

Figure 4. - Salome et al., 2015 

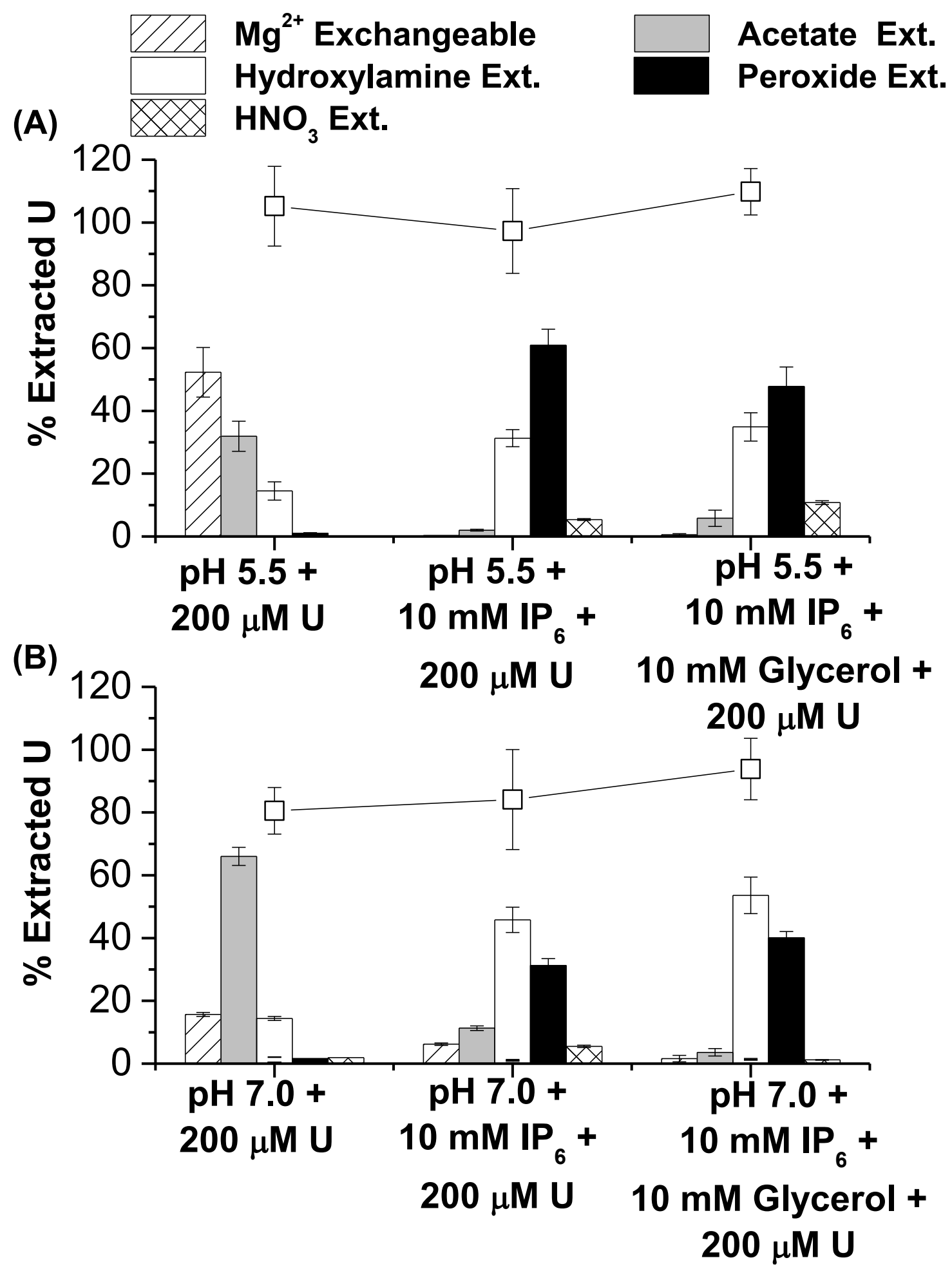

Figure 5.- Salome et al., 2015 

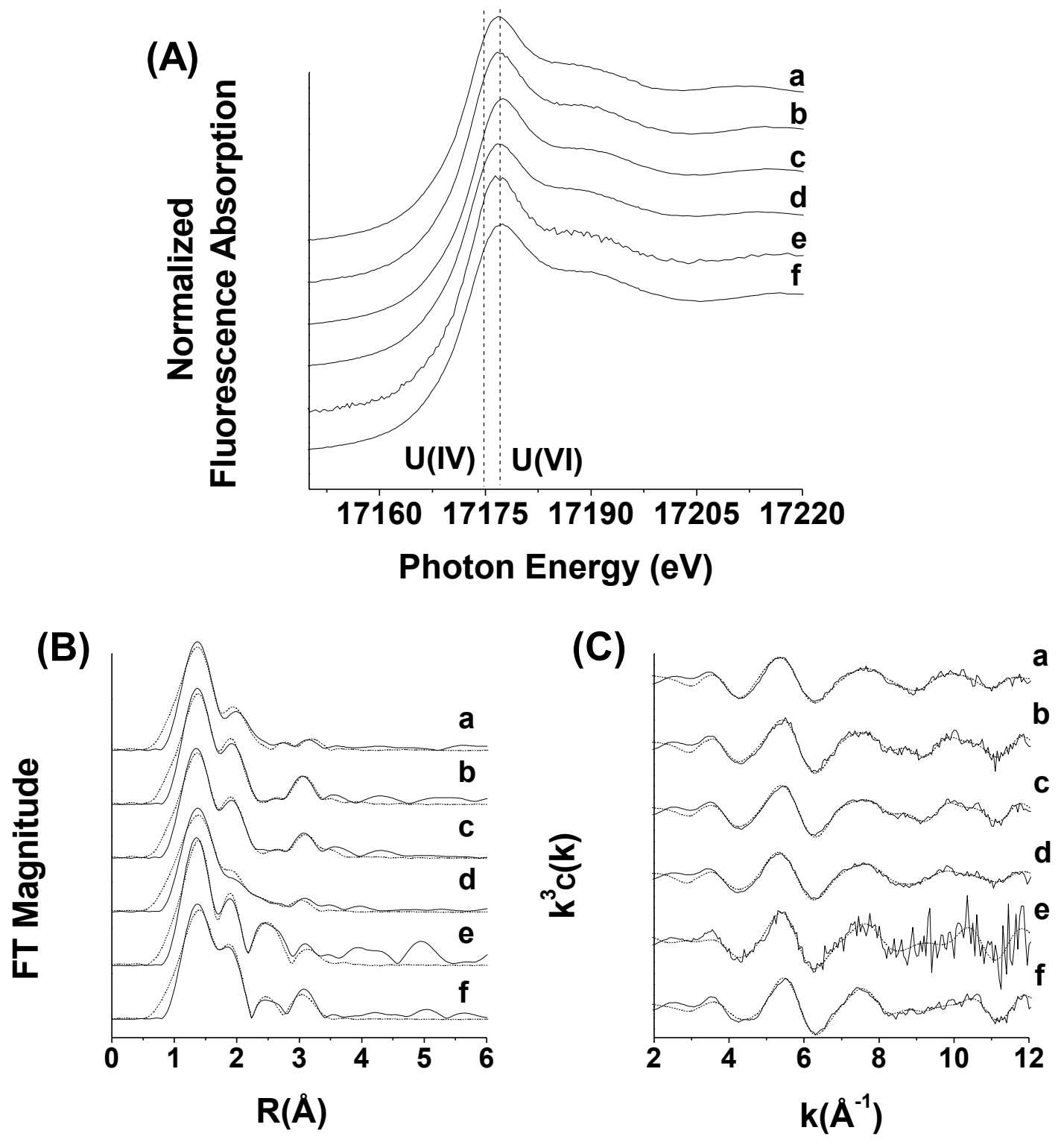

Figure 6.- Salome et al., 2015 